\title{
The Global Initiative
}

for Economic, Social and Cultural Rights

\section{Women's Participation in the Renewable Energy Transition:} A Human Rights Perspective 
Women's Participation in the Renewable Energy Transition: A Human Rights Perspective

BRIEFING PAPER 2 
Women's Participation in the

Renewable Energy Transition:

A Human Rights Perspective

This Briefing Paper Is published by the Global Initiative for Economic, Social and Cultural Rights

November 2021

Edited by Alejandra Lozano in collaboration with Tom Bagshaw and Juliette Wyss.

Supervised by Rodrigo Echecopar and Magdalena Sepúlveda Carmona.

With contributions from the following civil society organizations:

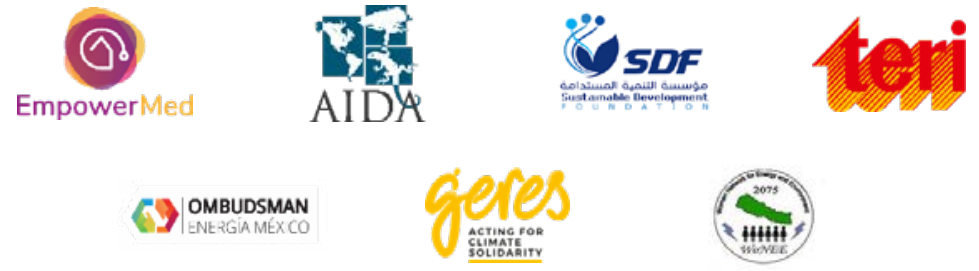

GI-ESCR wishes to thank Marine Cornelis, Executive Director of Next Energy Consumer for her comments on this briefing paper.

This publication has received the support from:

\section{FRIEDRICH EBERT STIFTUNG}

\section{DESIGN}

Tania Hernández • tallerhojarasca.com contacto@tallerhojarasca.com

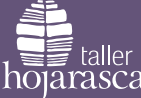

@ 2021 Global Initiative for Economic, Social and Cultural Rights. 


\section{Table of Contents}

Executive Summary 5

Introduction 11

International Human Rights Framework

12

Power, Gender and Participation 15

Forms of Participation 16

Who Participates? 18

Status and Trends of Women's

Participation in Key Decision-Making

Spaces in the Energy Transition 21

Women's Participation in Energy Planning and Leadership Policy Making 22

Women's Participation in Consultations and Community Level Energy Planning 23

Women's Participation in the Renewable Energy Workforce 25

Women's Participation in Productive Energy Uses 28

Women's Participation in Climate and Energy Finance 30

Women's Participation in Urban Planning and Development 31

Recommendations to Advance Women's Participation in the Energy Transition 33

Legal Framework and Accountability 33

Ensure Gender Equality in Legal and Institutional Energy Frameworks 33

Business Enterprise's Human

Rights Obligations 36

Ensuring Accountability in Energy-Related Participatory Processes 38

Data Collection, Access to Information and Transparency 38
Collect Gender Disaggregated Data 38

Ensure Transparency and Access

to Information 39

Education, Training and Employment 41

Combat Harmful Gender Roles

and Stereotypes 41

Provide Training and Education

for Women's Participation

in the Energy Sector 45

Remove Barriers and Promote

Employment Opportunities

in Renewable Energy 45

Access to Universal Sustainable Energy and Appliances 49

Alternative Renewable Energy Sources and Electrical Appliances 49

Supporting Women's Traditional

Knowledge and Innovation Abilities 52

Gender-sensitive and Participatory

Decision-making 53

Ensure a Gender-Balanced Composition of Energy-Related Governance Bodies 53

Environmental and Human Rights Impact Assessments 54

Gender-Sensitive Consultation Processes 55

Enabling Platforms for Women

to Exchange Experiences,

Mutual Learning, and Organizing 58

Ensuring Women's Participation

in Urban Planning 61

Finance and Budgeting 61

Ensure Gender-Sensitive Finance

and Budgeting 61

\section{Annex 65}

International Legal Instruments 65 


\section{Executive Summary}

1

he energy transition has become imperative to halt the climate emergency. In order to guarantee that the transition is more equitable and just than its forbearers, States and other stakeholders must ensure women's right to participate in the energy transition.

The right to participation involves having a say, to be heard and take part in decision-making processes that affect one's life and interests. Even though energy policy impacts on gender inequality, many barriers remain to ensure the full, meaningful and effective participation of women in the energy transition. With a global shift in the energy paradigm, we have a chance to re-evaluate the relationship that energy has with social and gender justice, the environment, and the economic model.

\section{The Human Rights Framework}

One of the keyways to achieve women's meaningful participation in the energy transition is through leveraging international human rights law. The international human rights framework provides a wide range of norms, standards and principles that offer guidance to States and other stakeholders to articulate effective and meaningful mechanisms for rights-holders, especially in marginalized communities, as well as to participate in and shape the policies that affect their lives. At its core, the human rights framework provides normative and analytical tools to deliver energy justice by identifying and understanding how asymmetrical power relations operate and articulate responses to transform them. Thus, human rights law provides a compass for developing energy systems that are not only renewable, but socially just.

\section{Women's right to participate in the energy transition}

Given the vastness of the energy transition, it would be incorrect to homogenise women's participation within the transition. Nevertheless, three key points can be made: First, we must engage with the substance of energy policies or projects that purport to be "participatory" to identify how this participation took place and if it was truly effective. Secondly, we must acknowledge that certain energy projects -i.e, solar cookers- may be premised on gendered and unequal assumptions and 
thus reproduce gender inequality rather than contest it, and we must ensure that intersectional concerns are adequately addressed. This requires for example, undertaking a gender intersectional analysis and searching for 'participatory exclusions', disaggregating gender itself so women are also empowered to engage. Finally, questions of women's participation must be willing to engage openly with questions of power and politics.

\section{Status and trends of women's participation in key decision-making spaces in the energy transition}

Huge gaps remain in ensuring women's meaningful participation in energy planning and policy-making processes with women being largely underrepresented in leadership positions, from corporate to the diplomatic level at international negotiations. The lack of women's participation in positions of leadership is a key underlying factor that continues to replicate gender inequalities in the global efforts to decarbonize energy systems. Moreover, even though the renewable energy sector has a great potential for increased employment opportunities, women are largely under-represented within the sector and often hold traditionally as female perceived positions in secretarial and administrative, rather than technical and operative positions.

At the community level, energy policies and projects are rarely open to the participation of the public, and typically, stakeholders engaged in these industries fail to provide local communities, specially to local women, with relevant information or mechanisms to meaningfully participate. The negative impacts of large-scale renewable energy projects on local communities have resulted in differentiated and often disproportionate impacts on women's livelihoods and local ecosystems due to the lack of gender-responsive participation and engagement mechanisms with local communities. Women's exclusion is further aggravated by formal consultation processes that fail to adopt an intersectional gender lens and do not implement measures to remove barriers that prevent local women from participating. Therefore, if targeted gender-transformative interventions are not implemented, existing patterns of gender segregation and discrimination in the traditional fossil-fuel energy sector will continue to be replicated in the renewable energy system.

However, the off-grid renewable energy system provides innovative opportunities to develop energy solutions responsive to local and gender differentiated needs, providing access to energy to communities living in poverty, and for engaging women in the management, generation and distribution of renewable energy solutions.

\section{Women's participation in productive uses of energy}

Due to gender norms and social practices, women are often associated with household activities and are the main users and suppliers of community and household energy. They are also largely responsible for the provision of biomass for energy purposes when 
their household don't have access to electricity. These conditions of energy poverty often have severe consequences on their health, as biomass fuels used for cooking cause lower respiratory diseases which often end fatally. Annually, close to four million people die prematurely from illnesses attributable to household air pollution, such as pneumonia, lung cancer and chronic respiratory diseases from biomass combustion paired with kerosene.

While women tend to be responsible for providing household energy, men are commonly the main decision makers when energy and electrical appliances must be acquired. Therefore, traditionally women have also had less access to energy and electrical appliances needed for the mechanisation of productive activities at the household level and beyond. This lack of power over automated production compels many women to perform economic activities with low levels of productivity, precarious working conditions, and high levels of drudgery. Women's participation in the use and control over energy resources and technology is essential to ensure women's safety and wellbeing.

\section{Women's participation in finance and budgeting}

The overall investments in the energy transition and in energy access at the local, national, and international levels are not flowing toward sustainable energy solutions that promote women's participation in the energy sector. The current interest of the financing world currently still lies on large-scale energy projects and do not consider small-scale, decentralised renewable energy projects which could enhance women's participation while fostering several co-benefits to open new economic opportunities and combat energy poverty. Also at State level, energy projects and policies fail to incorporate a gender perspective in tax policies and their energy budgeting to direct resources for the advancement of gender equality. Furthermore, women face structural gendered barriers to access financial and banking services and often fail to access adequate credits and loans. These restricted financial conditions significantly limit women's participation in the energy transition.

\section{Women's participation in urban planning and development}

Currently, cities contribute with $71-76 \%$ of all energy-related greenhouse gasses driving the climate emergency. Local governmental action is, therefore, key to address these challenges and take advantage of the opportunities arising from the energy transition. However, women's participation in these key decision-making spaces and gender-sensitive responses to urban planning and climate policy is still absent in most urban areas.

\section{Policy recommendations: the way forward}

Taking the above into consideration, the briefing paper makes the following key policy recommendations for stakeholders to adopt a 
rights-aligned approach to women's participa-

tion in the energy transition:

1. Legal Framework and Accountability

- Establish legal and institutional energy frameworks should explicitly include the principles of non-

discrimination, gender equality, and the right of women to participate on an equal footing with men across the energy sector.

- States have a positive obligation to regulate private actors to ensure their activities do not encroach upon fundamental rights, including women's right to participation. The duty of States to regulate the activities of private actors should also address business-related human rights impacts to the right to participation throughout the energy supply chain and in all territories under their jurisdiction.

- The establishment of participatory processes and mechanisms in the context of the energy transition need to be subjected to oversight and accountability to ensure they comply with human rights standards and gender equality principles. This involves from instituting effective monitoring and evaluation of participatory process to the provisioning of sufficient resources and training to the judiciary and law enforcement system to enhance judicial oversight to avoid or, in any case, redress any encroachment upon women's right to participation.
2. Collection of Data, Access to Information and Transparency

- Develop and compile gender disaggregated data with an intersectional lens to adequately consider the full scope of the gendered impacts of energy transition policies and projects, as well as of women's role in the development, design, adaptation, and use of renewable energy technologies.

- Ensure transparency and access to information is crucial for women to be able to participate at all levels of the energy transition to new sustainable and more equal energy systems. States and corporate actors leading renewable energy policies, programmes and projects should provide timely, sufficient, and objective data to the public, in accessible formats, and via appropriate channels, to be able to participate in decision-making. To be effective, these efforts need to consider gender differentiated needs of the rights-holders specially affected by these measures.

\section{Education, Training and Employment}

- Combat harmful gender roles and stereotypes in the energy field.

This includes, on one hand, how women perceive themselves, and on the other, how the State, families and communities perceive women in the energy sector in order to change harmful social practices 
and norms that exclude women

form participating in energy systems.

- States and relevant stakeholders driving the energy transition need to provide quality education and training services in STEM subjects and other key energy-related education programs to ensure women in all their diversity develop their skills and talent as managers, negotiators, technicians, administrators, and providers of sustainable energy solutions and allow them to meaningfully participate at all levels of decision making in the global transformation of energy systems.

- States and other stakeholders must remove barriers of women's employment at all levels of the renewable energy sector providing more flexible working arrangements for a better life-work balance, training opportunities for women, including mentoring programmes, and combating gender stereotypes in the energy sector.

\section{Access to Sustainable Energy} and Appliances

- States must provide universal access to safe, reliable, and sustainable energy sources, prioritizing communities currently living in energy poverty. This could be achieved by fostering different forms of decentralized, locally owned and women-led renewable energy systems that can provide better opportunities to bridge energy access gaps and for women to meaningfully participate in the production and distribution of sustainable energy.

- States should adopt a holistic approach to access to sustainable energy not only by ensuring the provision of renewable energy sources but also the acquisition and use of energy efficient electrical appliances (i.e. clean cooking stoves, lights, fans, mills, water pumps, refrigerators, washing machines, etc.) able to transform the energy into productive energy services at the household level and for other key economic activities.

- Support women's local and traditional knowledge and skills for the development of culturally adequate renewable energy systems and energy efficient technologies and infrastructure.

5. Gender-Sensitive and Participatory Decision-Making

- States should take necessary steps to achieve a gender-balanced composition of the bodies intervening at all stages of energy decision-making. This should be promoted through multifaceted approaches that are responsive to the challenges faced by women due to intersectional forms of discrimination.

- Impact evaluation assessments of renewable energy projects must be participatory and comprehensive. 
They must evaluate gender differentiated impacts, incorporate human rights principles, and be developed with the meaningful participation of all women and girls specially affected by energy policies or projects.

- Consultation processes must be held with indigenous and local communities that are mostly affected by energy projects and policies.

The consultation processes should be designed and implemented according to international human rights standards in a manner that allows all persons regardless of their gender to equally participate.

- States should support and protect platforms for women to learn, exchange experiences, strategize, and organize, which is key to ensure their meaningful participation in the energy transition. This involves the creation of spaces and platforms for women to feel comfortable to share their views, have peer-to-peer exchanges, identify common challenges and demands, as well as to coordinate with others to influence decision-making processes.
- Cities should foster new urban planning and development by incorporating mechanism to enhance women's participation in local governments and promote measures to encourage women to promote efficiency measures in buildings and public facilities, support decentralized women-led renewable energy infrastructure in urban settings and organize public campaigns to encourage transformative changes in citizens' consumption patterns to save energy among higher income consumers.

\section{Finance and Budgeting}

- States and other stakeholders must promote gender-responsive financing of energy projects and policies that deliver gender equal outcomes and promote women's participation as key agents of change in the articulation of socially inclusive and sustainable energy solutions. To this end, it is key to incorporate a gender approach to tax policies, Sate budgeting and to financial services providing credits and loans for the development of renewable energy projects. 


\section{Introduction}

T he energy transition is imperative to halting the climate emergency. However, decarbonizing energy systems does not imply these will automatically deliver more equitable and just outcomes than their fossil fuel forebears. Participatory frameworks that prioritize the needs of those who have been historically discriminated against and marginalized need to be established. This will ensure that the global transformation distributes its benefits and costs, while pursuing broader goals to advance democratic governance, gender equality and human rights as well as ultimately contributing to the transition from an extractive to a sustainable and regenerative economy.

The massive energy transformation opens a unique possibility to shift gender power imbalances and ensure women's voices, perspectives and knowledge are harnessed to steer the energy transition and stage the future of renewable energy with a human rights and gender perspective. This poses several questions. How can we create participatory frameworks and spaces that create meaningful opportunities for marginalized women to influence the course of the energy transition? What measures should be advanced to strengthen gender equality and democratic governance? What energy models and alternatives can better accommodate women's needs and enhance their opportunities to participate at all levels of decision-making?

To answer some of these questions, this briefing paper will, firstly, identify the key international norms and standards governing women's right to participate in the context of the energy transition. It also provides a comprehensive list of the main international human rights provisions, alongside environmental and sustainable development frameworks. Secondly, it explores the meaning and contested dimensions of women's right to participate and the underlying gendered power structures in the energy transition, to provide a framework to evaluate women's participation in the energy transition from a human rights approach. Thirdly, the briefing analyzes the status and trends of women's participation in key spheres of decision-making; specifically, energy planning and leadership in decision-making, consultation processes at the community level, the energy workforce and in productive energy uses, as well as in climate finance and in urban planning and development. Finally, the brief concludes providing 
a set of policy recommendations that States and other stakeholders driving the energy transition should adopt to ensure a rights-aligned approach to women's participation in the energy transition and guarantee their views and perspectives contribute to shaping the global green-energy transformation.

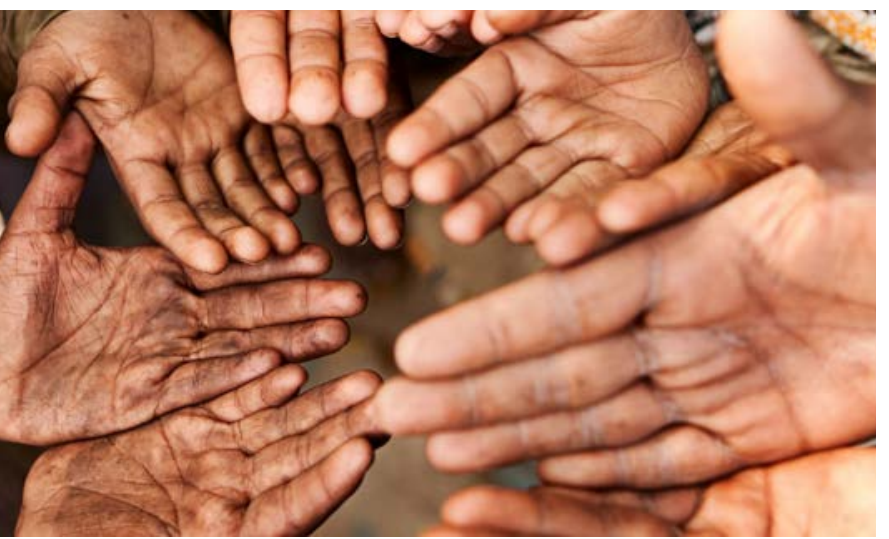

\section{International Human Rights Framework}

$\mathrm{T}$ he right to participation is a procedural right that, when meaningfully implemented, can radically shift power imbalances and articulate responsive and effective policies for rights-holders which are more likely to achieve their intended outcomes.

Building on the concepts of environmental and climate justice, the concept of energy justice emerged from academics and social movements in the early 2010s to address the justice issues concerning energy access, use and decision-making. ${ }^{1}$ Energy justice is defined as a global energy system that fairly distributes the costs and benefits of the production and consumption of energy services, as well as one that is fair in how it treats people and communities in decision-making. ${ }^{2}$ Energy justice has evolved into a framework with three main components to be considered throughout the energy system: distributive, recognitional, and procedural. ${ }^{3}$ These dimensions address the question related

\footnotetext{
* All websites have been last accessed on June-July 2021.

1 Feenstra, M. and Özerol, G., "Energy Justice As a Searchlight for Gender-Energy Nexus: Towards a Conceptual Framework.' Renewable and Sustainable Energy Reviews, Volume 138, 110668, 110668, 2021, ISSN 1364-0321, ss.

2 Sovacool, B.K. and Dworkin, M.H., Global Energy Justice: Problems, Principles and Practices, Cambridge University Press, 2014, p. 5.

3 Ibid. no. 1
} 
to where should the energy resources be focused (distributive justice), whose needs should be recognized (recognitional justice) and how democratic governance and participation in decision making should function (procedural justice). The latter, concerning procedural energy justice, refers to the governance structure of energy systems and is inextricably linked to the realization of the right to participation enshrined in the International Human Rights framework. Who gets to decide and set energy rules and programs? By what processes do they make such decisions? And, how fair are these institutions, instruments and processes? These are key questions that define procedural energy justice. The fulfilment of the right to participation in pursuit of procedural energy justice is thus essential to ensure human dignity and is one of the core elements of human-rights approaches aimed at eliminating conditions of marginalization and discrimination. ${ }^{4}$ Fair decision-making procedures matter not only because they are a recognized human right, but also because they tend to promote more equitable and effective outcomes and decisions. By ensuring all voices are represented, decisions are more likely to address specific needs through the most effective solutions as well as have the support of rights-holders.

Despite the critical importance of realizing this right without discrimination, in practice women in all their diversity have historically been discriminated and marginalized from decision-making spaces across sectors and disciplines. Due to patriarchal norms and gender stereotypes, women face multiple cultural and material barriers that restrict their possibilities to meaningfully participate in public affairs and decision-making. These barriers are particularly significant in the energy sector, insofar as it has remained one of the most male dominated industries, characterized by its lack of gender diversity and its pervasive gender-blindness in policymaking. ${ }^{5}$

Currently, only a small share of women hold leadership positions in energy planning and policymaking. ${ }^{6}$ Women's participation in the fossil fuel and growing renewable energy sectors workforce is significantly below the overall average of women participating in the global workforce. ${ }^{7}$ This lack of women's participa-

\footnotetext{
4 Office of the High Commissioner for Human Rights (OHCHR), "Factors that Impede Equal Political Participation and Steps to Overcome Those Challenges," 2014, UN Doc A/HRC/27/29.

5 International Renewable Energy Agency (IRENA), "Renewable Energy: A Gender Perspective," 2019, p. 58 , ss.

6 United Nations Industrial Development Organization (UNIDO) and UN Women, "Sustainable Energy for All: The Gender Dimensions," 2013, ss.

7 Ibid. no.5, See also: International Energy Agency (IEA), "Tracking Gender and the Clean Energy Transition," 2018, ss.
} 
tion in the energy sector has significant impacts in terms of representation and equal rights of women to benefit from the energy transition. As is often the case with other development projects, large-scale energy infrastructure installation and operation have multiple adverse impacts for the environment and local communities, often disproportionately affecting women and girls. ${ }^{8}$

The energy transition implies a complex global transformation that requires not only moving from a dominant fossil-fuel based system to renewable energy sources, but also implementing measures to increase energy efficiency and reduce energy consumption globally while ensuring universal access and the protection of the environment. While there are no fixed answers to meet these ambitious goals, it does require us to question for whose benefit, for what purposes and under whose control energy will be produced and distributed in new energy models. To ensure we move toward a framework of energy justice, we not only need to decarbonize energy systems but transform them. ${ }^{9}$ We need a shift in the energy paradigm. This means re-evaluating the relationship that energy has with social and gender justice, the environment and the economic model. ${ }^{10}$ To achieve this aim, it is critical to realize women's right to participate.

While efforts and promising practices to engage communities and enhance women's participation are significant, the lessons learned in that context require scaling-up and must be shared with wider audiences and stakeholders to ensure they have a larger impact in the global energy transition. One of the key ways to achieve this is through leveraging international human rights law. The international human rights framework provides a wide range of norms, standards and principles that offer guidance to States and other stakeholders to articulate effective and meaningful mechanisms for rights-holders, especially in marginalized communities, as well as to participate in and shape the policies that affect their lives. At its core, the human rights framework provides normative and analytical tools to deliver energy justice by identifying and understanding how asymmetrical power relations operate and articulate responses to transform them. ${ }^{11}$ Human rights law provides a compass for developing energy systems that are not only renewable, but socially just.

\footnotetext{
8 International Union for Conservation of Nature (IUCN) and US Agency for International Development (USAID), "Advancing Gender in the Environment: Making the Case for Gender Equality in Large-Scale Renewable Energy Infrastructure Development," AGENT Thematic Brief Series, 2018, ss.

${ }^{9}$ Fairchild, D. and Weinrub, A.I., "Introduction," in Fairchild, D. and Weinrub, A.I. (eds), Energy Democracy: Advancing Equity in Clean Energy Solutions (Island Press, 2017).

10 Ibid.

11 Human Rights Council (HRC), Report of the Special Rapporteur on Extreme Poverty and Human Rights, Magdalena Sepúlveda Carmona, 2013, UN Doc A/HRC/23/36, paragraph 17. See also: ActionAid, "People's Action in Practice: ActionAid's Human Rights Approach 2.0" (2012), ss.
} 
In that light, a rights-aligned approach to participation could open new avenues to ensure women in all their diversity contribute as users, producers and leaders of a gender-just transition to renewable energy and set the path toward a more equal, just, sustainable and regenerative economy.

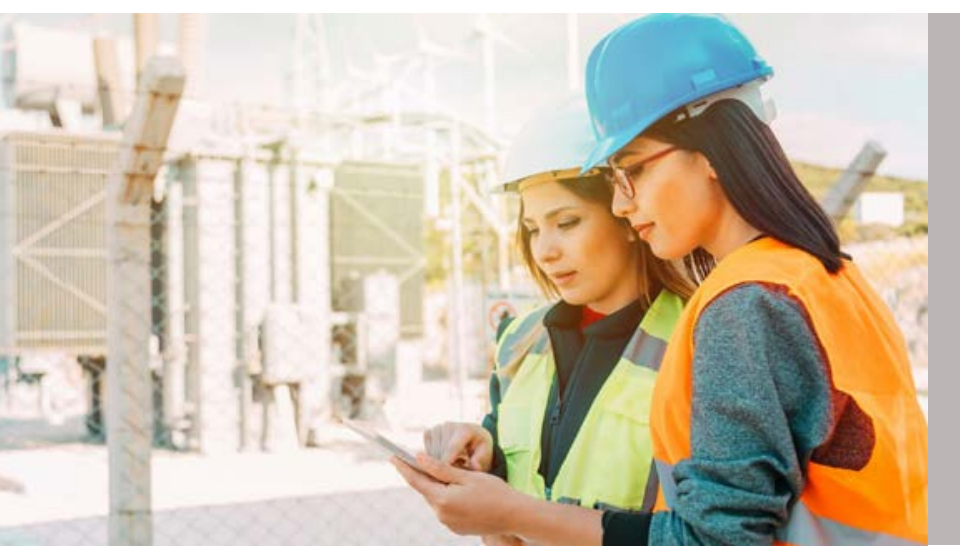

\section{Power, Gender and Participation}

$\mathrm{P}$ articipation can mean many different things in different contexts. It involves a long and varied conceptual history and the capacity to impose radically different meanings in political and economic spheres. ${ }^{12}$ As a development concept, it was arguably born of radical roots, having been closely associated with a counter-hegemonic desire to include those previously excluded and transform cultural, political and economic structures responsible for poverty and marginalization. ${ }^{13}$ Despite this beginning, in recent years development stakeholders of all ideological shades, at least on the surface, have widely embraced participation. ${ }^{14}$ The ostensibly stable consensus that has developed

12 Stiefel, M. and Wolfe, M., The Many Faces of Participation, in A Voice for the Excluded: Popular Participation in Development: Utopia or Necessity? Atlantic Highlands, NJ: Zed Books in association with the United Nations Research Institute for Social Development (UNRISD), 1994.

13 Leal, P.A., "Participation: The Ascendancy of a Buzzword in the Neo-Liberal Era," 2007, p. 17 (4-5) Development in Practice, pp. 539-48. This counterhegemonic potential is visible in the UN Research Institute for Social Development's working definition of participation as "the organized efforts to increase control over resources and regulative institutions in given social situations, on the part of groups and movements hitherto excluded from such control."

14 Evelina Dagino, for example, describes the existence of a "perverse confluence" between the participatory and the neoliberal projects, both of which have embraced a "common vocabulary." Dagino, $E$. "Citizenship: A Peverse Confluence", in The Participation Reader, ed. Andrea Cornwall, Zed Books, 2011. On participation as a development "buzzword," see also Cornwall, A. and Brock, K., "What Do Buzzwords Do for Development Policy? A Critical Look at 'Participation', 'Empowerment' and 'Poverty Reduction,'" 2005, 26(7) Third World Quarterly 26, and Leal, P.A., "Participation: The Ascendancy of a Buzzword in the Neo-Liberal Era", 2007, 17(4-5) Development in Practice. 
around the importance of participation, however, has served to obscure deeper conflicts over its meaning and function.

In order to analyze the tensions and conflicts inherent in the right to participation, we will look at two dimensions of this procedural right, specifically a) the form that participatory processes take and $b$ ) the question of whom they enable to participate. We will consider the relevance of these insights for the question of women's full and effective participation in the renewable energy transition.

\section{Forms of Participation}

To be effective, participation should occur in all stages of an energy policy or project. Four stages can be identified in participation from a linear perspective. They are initial decision-making; implementation, whether it be through resource contribution, coordination or enlistment in a program; results related to the project's benefits, whether material, social, or personal; and evaluation. A holistic understanding of participation accounts for each of these stages and is sensitive to the possibility that people's effective participation in one stage may overshadow the reality that they are not engaged in others. This risk is particularly acute in relation to women's participation in development projects, which is often limited to the implementation stage where they are expected to take on additional forms of gendered labor by, for instance, taking care of children while their partner and herself work in the energy infrastructure installation process. ${ }^{15}$

This linear understanding of participation may be contrasted with more normative approaches assessing participation in accordance with the intensity with which participants are engaged. In this view, participation must result in a redistribution of power so as to ensure that those excluded from political and economic processes are deliberately included in the future. ${ }^{16} \mathrm{~A}$ classic 'ladder of participation' thus proposes three levels: at the lowest, manipulation, which does not involve the genuine involvement of individuals but rather an "education" by powerholders; next is tokenism, which involves processes where people may be given a voice through consultation and placation but their views have no meaningful impact; and finally "citizen power," which involves genuine participation where citizens have a degree of real control over planning and decision-making.

\footnotetext{
15 Cornwall, A., "Whose Voices? Whose Choices? Reflections on Gender and Participatory Development.", in The Participation Reader, ed. Cornwall, A. (Zed Books, 2011).

16 Arnstein, S.R. "A Ladder of Citizen Participation", Journal of the American Institute of Planners, 1969, 35(4).
} 
This approach helps us recognize that many processes that are labelled as "participatory" are in fact designed to serve majority interests and do not comply with international human rights standards to ensure procedural justice.

It is concerning that contemporary participatory processes so regularly neglect questions of power and politics, arguably a precondition for delineating those that are transformative from those that exist to maintain the status-quo. As participation has ascended to mainstream discourse, it has become increasingly technical, a method of project work "purged of all the threatening elements" and "liberated from any meaningful form of social confrontation." 17 Its language of empowerment has come to obscure a preoccupation with managerial effectiveness and efficient service delivery, while maintaining broader structures of domination and powerlessness. ${ }^{18}$ In this sanitized and depoliticized form, it has been mobilized to render policy prescriptions palatable, to marshal the marginalized in favor of specific projects, and to neutralize challenges. ${ }^{19}$

The issues highlighted above do not foreclose the potential for participation to transform unjust economic, social and political structures. ${ }^{20}$ Examples of genuine social transformation are evident in each field in which participation plays a major role, such as participatory governance and democratic decentralization; NGO projects and advocacy, small-scale community development projects and social movements' activities. ${ }^{21}$ These instances of full and effective participation share a number of common features, most notably that they are neither value-free nor geared towards sudden status-changes, but rather constructed

17 Kothari, U. and Cooke, B. "The Case for Participation as Tyranny," in Participation: The New Tyranny?, ed. Cooke, B. and Kothari, U., Zed Books, 2001; Leal, P.A., "Participation: The Ascendancy of a Buzzword in the Neo-Liberal Era", 2007, 17(4-5) Development in Practice; Williams, G., "Towards a Repoliticalization of Participatory Development: Political Capabilities and Spaces of Empowerment," in The Participation Reader, ed. Cornwall A. (Zed Books, 2011).

18 Kothari, U. and Cooke, B. "The Case for Participation as Tyranny," in Participation: The New Tyranny?, ed. Cooke, B. and Kothari, U. (Zed Books, 2001).

19 Leal, P.A., "Participation: The Ascendancy of a Buzzword in the Neo-Liberal Era," 2007, 17 (4-5) Development in Practice; W Williams, G., "Towards a Repoliticalization of Participatory Development: Political Capabilities and Spaces of Empowerment," in The Participation Reader, ed. Cornwall A., Zed Books, 2011; Dagino, E. 'Citizenship: A Perverse Confluence,' in The Participation Reader, ed. Andrea Cornwall, Zed Books, 2011.

20 The widespread institutional acceptance of participation arguably entails that recovery of the transformative potential of participation can have far reaching effects. The stakes are high. See Leal, P.A., "Participation: The Ascendancy of a Buzzword in the Neo-Liberal Era," [2007] 17 (4-5) Development in Practice; Williams, G., "Towards a Repoliticalization of Participatory Development: Political Capabilities and Spaces of Empowerment," in The Participation Reader, ed. Cornwall A., Zed Books, 2011.

21 Hickey, S. and Mohan, G. "Relocating Participation Within a Radical Politics of Development," 2005, 36 (2) Development and Change. 
as a part of a broader, long-term-and potentially reversable-project that does not shy away from engagement with issues of power relations, politics and structural inequalities. ${ }^{22}$ Crucially, effective examples of participation also tend to articulate a form of participation as citizenship, seeking to include individuals in existing processes and enabling them to reshape these processes in a more inclusive, sustainable, and democratic direction, which alters the very way in which they can claim rights and resources. ${ }^{23}$

This notion is at the core of a rights-based participation: a participation that effectively challenges power networks, reshapes patterns of political representation and empowers participants to project their agency beyond the context of specific interventions. ${ }^{24}$

\section{Who Participates?}

Our second dimension of rights-based participation concerns the question of who is enabled to participate in a given project, policy or initiative. Participatory processes designed to empower communities have long made the mistake of treating these communities as a homogenous analytic unit, obscuring that individual characteristics, power relations, inequalities and local politics have a structural impact on engagement and knowledge production. ${ }^{25}$ Specific mechanisms are required to secure the participation of disadvantaged groups to avoid excluding large sections of communities they claim to benefit.

Women's exclusion from participation in institutions, policies and projects is often the result of systemic inequalities that predate the participatory process in question. ${ }^{26}$ These deep-rooted determinants of women's participation include

22 Hickey, S. and Mohan, G. "Relocating Participation Within a Radical Politics of Development," 2005, 36 (2) Development and Change; Williams, G., "Towards a Repoliticization of Participatory Development: Political Capabilities and Spaces of Empowerment,", in The Participation Reader, ed. Cornwall A., Zed Books, 2011.

23 Hickey, S. and Mohan, G. "Relocating Participation Within a Radical Politics of Development," (2005) 36 (2) Development and Change; Williams, G., "Towards a Repoliticalization of Participatory Development: Political Capabilities and Spaces of Empowerment," in The Participation Reader, ed. Cornwall A. (Zed Books, 2011).

24 Ibid.

25 See, inter alia, Guijt, I and Shah, M., The Myth of Community: Gender Issues in Participatory Development (Intermediate Technology Publications, 2001); Mosse, D. "Authority, Gender and Knowledge: Theoretical Reflections on the Practice of Participatory Rural Appraisal," (1994) 25 (3) Development and Change.

26 Agarwal, B. "Participatory Exclusions, Community Forestry, and Gender: An Analysis for South Asia and a Conceptual Framework," (2001) 29 (10) World Development. 
social norms that govern who should attend meetings and how they should act during discussions, social perceptions concerning the ability of women to make meaningful contributions, personal endowments and attributes such as education levels, property status, marital status and age; household endowments such as socio-economic status and caste, as well as the degree to which men's interests are already entrenched within a given community. Depending on their design and implementation, participatory processes that intersect with underlying inequalities can either reproduce and entrench them further or provide an opportunity to address them and weaken their influence. Women's capacity to challenge and overcome barriers to participation will ultimately be dependent on the bargaining power they can exert in relation to the State, their communities, the market and their families. ${ }^{27}$ The level of bargaining power that women possess may be bolstered by support from external agents such as gender-progressive elements of the State, NGOs, private actors or international organizations, ${ }^{28}$ as well as by promoting (or removing barriers from) women's autonomous organization.

Interventions that are designed to enhance women's participation are not without complexities, particularly with respect to the question of when certain women's voices should be understood as representative of women in general. ${ }^{29}$ Well-intentioned efforts to increase women's participation often run the risk of essentializing women as a single category, neglecting the possibility that in some instances women may more readily identify their interests as lying with their sons and wider family. It risks imposing Western understandings onto local dynamics, while negating the intersection of characteristics such as age, caste, race, sexual orientation, gender identity, disability and class. ${ }^{30}$ The token presence of women in inadequate participatory schemes may also be used as a means of legitimizing decisions over which women have had no influence, reproducing inequitable gender relations while creating the impression that exclusion issues have been addressed..$^{31}$ Or it may be that women fully engage with

\footnotetext{
27 Ibid.

$28 \mathrm{Ibid}$. Although Agarwal developed her conceptual framework in the context of community forestry in South Asia, it is explicitly envisaged to have broader application beyond forestry and the Global South.

${ }^{29}$ Cornwall, A., "Whose Voices? Whose Choices? Reflections on Gender and Participatory Development," in The Participation Reader, ed. Cornwall, A. (Zed Books, 2011).; White, S.C., "Depoliticizing Development: The Uses and Abuses of Participation," (1996) 6 (1), Development in Practice.

30 Cornwall, A., "Whose Voices? Whose Choices? Reflections on Gender and Participatory Development," in The Participation Reader, ed. Cornwall, A. (Zed Books, 2011).

31 White, S.C., "Depoliticizing Development: The Uses and Abuses of Participation," [1996] 6 (1), Development in Practice. Cornwall, A., "Whose Voices? Whose Choices? Reflections on Gender and Participatory Development."
} 
projects and policy making but, in doing so, advance ideals that many feminists and women's rights groups would think of as oppressive and which reinforce existing gendered divisions of labor and other gender stereotypes and gendered social practices, ${ }^{32}$ or which do not duly address intersectional concerns. Then it is presumed that women form a single category and participation is limited to the collection of sex-disaggregated data; "gender-blindness" may simply be replaced with a form of "gender blinkeredness".33

Rights-based participatory initiatives should be open to dynamics that come from different and divergent points of view, sensitive to intersectional gender concerns and capable of dealing with the rich variety of social experiences that emerge from everyday life. They require persistent advocacy to remove barriers and enable favorable conditions for women to participate, as well as explicit efforts to create spaces in which women are also able to raise their voices. As highlighted by Cornwall: "Whether by reconfiguring the rules of interactions in public spaces, enabling once silent participants to exercise voice, or reaching out beyond the "usual suspects" to democratize decision-making, such processes can help transform gender-blindness and gender-blinkeredness into the basis for rights-based alliances to confront and address power and powerlessness." 34

\footnotetext{
32 Cornwall, A., "Whose Voices? Whose Choices? Reflections on Gender and Participatory Development," White, "Depoliticizing Development."

33 Ibid.

34 Ibid.
} 


\section{Status and Trends of Women's Participation in Key Decision-Making Spaces in the Energy Transition}

T he renewable energy transition is itself a vast and diverse phenomenon that consists of a range of policies, legal frameworks, projects and targets that span radically different contexts across the globe and operate at macro, mezzo and micro levels. This makes it challenging to speak of women's participation in the renewable transition in any singular sense. Our understanding of what participation requires will ultimately differ depending on the context.

Three key lessons can be highlighted. First, we must engage with the substance of energy policies or projects that purport to be "participatory" to identify how this participation took place and if it was truly effective. Secondly, we must acknowledge that certain energy projects-say, solar cookersmay be premised on gendered and unequal assumptions and thus reproduce gender inequality rather than contest it. We must ensure intersectional concerns are adequately addressed, for example, by undertaking a gender intersectional analysis and searching for "participatory exclusions," disaggregating gender itself so women are also empowered to engage. Thirdly, questions of women's participation must be willing to engage openly with questions of power and politics.

A rights-based participation based on equality and non-discrimination, respect of autonomy as well as dignity, and that fully implements human rights and environmental international standards should seek to reveal the interests served by a given instance of women's participation. And be willing to challenge instances when it is instrumentally advanced by powerful actors, including transnational corporations and other business enterprises. Finally, it must engage with women's rights organizations and feminist social movements, which often have had the opportunity to articulate means to move forward. They can also offer the opportunity to build women's networks that can be actively engaged in decision-making processes, connect with rights-holders and build long-lasting relationships with decision-makers. 
We will now look at specific sectors within the energy transition to identify key ways to ensure women's rights-based participation in energy planning and policy making, consultation and community-level planning, productive energy uses, women's participation in renewable energy at the level of the traditional workforce and in alternatively distributed renewable energy systems, as well as in finance and urban planning and development.

\section{Women's Participation in Energy Planning and Leadership Policy Making}

Huge gaps remain in ensuring women's meaningful participation in energy planning and policy-making processes. A 2013 study shows that in important national government positions, only $7 \%$ of the high-ranking officials in the energy, environment and natural resources ministries worldwide are women; only 3\% are female public officials in science and technology. ${ }^{35}$ Even in developing countries where the gender gaps in decision-making positions have greatly improved in recent decades, newer studies show that women do not participate in executive positions at top energy enterprises. ${ }^{36}$

In a more comprehensive study published by the Organization for Economic Cooperation and Development (OECD) and the International Energy Agency (IEA), which evaluated 2,500 energy enterprises classified in the fossil fuel and renewable energy sectors, women represented only $14 \%$ of all senior manager positions. ${ }^{37}$ Specifically in the renewable energy sector, despite efforts undertaken by State and private stakeholders to make it more inclusive, the wide gender gap is not significantly different. Women in leadership positions in renewable energy companies represent $10.8 \%$, only slightly higher than in the coal sector. ${ }^{38}$

Furthermore, in international negotiations in which energy and climate change issues are discussed, most negotiators are men. The average percentage of women across national delegations at the UNFCCC increased from $30 \%$ in 2008 to $39 \%$ peaking at $40 \%$ in $2018 .{ }^{39}$ Women also represented $37 \%$ of the

\footnotetext{
35 UNIDO and UN Women, Sustainable Energy for All: The Gender Dimensions, 2013, ss.

36 Ibid.

37 Pilgrim, Graham et al., "Women in Senior Management Roles at Energy Firms Remain Stubbornly Low, But Efforts to Improve Gender Diversity are Moving Apace,' 2021, ss. 
attendees to the annual Conference of the Parties (CoP25) in 2019.40 In other relevant forums, such as the World Energy Council, women only occupy $4 \%$ of the chair and $18 \%$ of the ministerial positions. ${ }^{41}$ We can thus fairly say that the limited representation of women in senior positions at global energy and climate change fora is most likely reproducing an inadvertent male bias. ${ }^{42}$

The lack of women's participation in leadership positions is a key underlying factor that continues to replicate gender inequalities in global efforts to decarbonize energy systems. Empirical evidence suggests that greater gender diversity in governance bodies allows, at minimum, to incorporate a wider perspective to better take into account the views and needs of different social groups. ${ }^{43}$ Some studies go even further and argue women legislators' presence in certain contexts does make a difference in terms of more sustainable outcomes in energy policy-making. ${ }^{44}$ This underlines the critical need to encourage women's engagement and participation at top levels of policy-making and energy planning. This would be a key step forward to advance substantive gender equality, but high-level governance bodies and forums need to integrate gender concerns as key questions to address in their working programs as well as all their activities to fully integrate a gender perspective in the global energy transition.

\section{Women's Participation in Consultations and Community Level Energy Planning}

While being an important source of employment and economic benefits, the energy sector has been traditionally known for its negative social and environmental impacts. At the community level, energy policies and projects are rarely open to public participation, and typically, stakeholders engaged in these

\footnotetext{
40 Ibid.

41 IUCN, "Women in Environmental Decision-Making: New Research from the Environment and Gender Index (EGI)," 2015, ss. As cited in Rojas, A., Prebble, M. and Siles, J., "Chapter 4: Flipping the Switch, Ensuring the Energy Sector Is Sustainable and Gender-Responsive" in Aguilar, L., Granat, M, and Owren C. (eds), Roots for the Future (IUCN, 2015), ss.

42 United Nations Environmental Program (UNEP), Global Gender and Environment Outlook, 2016.

43 Ibid. See also: Modiba, E. M., and Ngwakwe, C. C., "Women on the Corporate Board of Directors and Corporate Sustainability Disclosure. Corporate Board: Role, Duties and Composition," 2017, 13 (2), 32-37.

44 Fraune, C., "The Politics of Speeches, Votes and Deliberations: Gendered Legislating and Energy Policy-Making in Germany and the United States," Energy Research \& Social Science 19, 2016, p.134-41.
} 
industries fail to provide local communities with relevant information or mechanisms to meaningfully participate. ${ }^{45}$ It is well documented, for instance, that if adequate safeguards are not implemented, large-scale renewable energy projects can replicate harmful extractive practices and result in negative human rights impacts commonly present in the fossil fuel energy sector. ${ }^{46} \mathrm{As}$ is the case with other mega development projects, renewable energy infrastructure installation and operation may result in changes in land use without fair compensation, displacement of local populations, restriction to access common natural resources, pollution and deforestation, as well as social conflicts and divisions among community members that, in the most severe cases, escalate to violent attacks and rising insecurity. ${ }^{47}$ For instance, in recent years Latin America and Southeast Asia have registered increased threats, intimidations and assassination of human rights defenders who opposed development of large-scale renewable energy projects. ${ }^{48}$

The negative impacts of large-scale renewable energy projects on local communities have resulted in differentiated and often disproportionate impacts on women's livelihoods and local ecosystems due to the lack of gender-responsive participation and engagement mechanisms with local communities. ${ }^{49}$ As large-scale renewable energy projects are land-intensive and women tend to have highly unequal land tenure rights, they are commonly marginalized from processes of negotiation, consultation and compensation between project developers and local communities..$^{50}$ Moreover, compensation schemes that do not take into consideration gender inequalities in land own-

45 UN Interagency Framework Team for Preventive Action and the European Union, "Toolkit and Guidance for Preventing and Managing Land and Natural Resources Conflict: Extractive Industries and Conflict," 2012, ss.

46 Business and Human Rights Resource Centre (BHRC), "Renewable Energy and Human Rights Benchmark Key Findings from the Wind and Solar Sectors," 2020, ss. See also OHCHR, Statement of Victoria Tauli-Corpuz, Special Rapporteur on the Rights of Indigenous Peoples, 17th Session of the United Nations Permanent Forum on Indigenous Issues, 2018, ss; HRC, Report of the Special Rapporteur on the Rights of Indigenous Peoples, 2017, UN Doc A/HRC/36/46.

47 Business and Human Rights Resource Centre, "Renewable Energy and Human Rights Benchmark Key Findings from the Wind and Solar Sectors," 2020), ss.

$48 \mathrm{Ibid}$. See also: Business and Human Rights Resource Centre, "(In)justicia energética en América Latina," 2021, ss

49 Umar, R., Nasution, M. and Dewy, P., "When the Energy Project Comes into Our Lives: An Executive Summary of the Compilation of Women's Stories, Aksi!" for Gender, Social and Ecological Justice, 2020, ss.

50 Global Initiative for Economic, Social and Cultural Rights (GI-ESCR), "Renewable Energy and Gender Justice," 2020, ss. 
ership, tend to result in women's dispossession and the erosion of the status of women in their communities. ${ }^{51}$

Women's exclusion is further aggravated by formal consultation processes that fail to adopt an intersectional gender lens and do not implement measures to remove barriers that prevent local women from participating. In 2016 the German government organized a participatory exercise with citizens to enhance public acceptance of the energy transition framework, but records show that women were significantly underrepresented in these participatory processes. ${ }^{52}$ Levels of women's participation in consultation process of large -scale renewable energy projects conducted with indigenous peoples tend to be strikingly low.

When women do not participate in these participatory processes, their rights tend to be especially affected and their perspectives are unable to inform energy policies and projects' design and implementation. This not only impacts women, but also the community at large, since empirical evidence suggests that women who participate in consultation processes are more prone to advocate for investments in schools, health centers, better community infrastructure and services as part of compensation plans of large-scale development projects. ${ }^{53}$

\section{Women's Participation in the Renewable Energy Workforce}

In terms of traditional renewable energy schemes, the rapid and worldwide scaled transition to renewable energies has opened up an unprecedented number of employment opportunities for millions of people in recent years. It is estimated the number of job openings in the sector could increase from 10.3 million in 2017 to nearly 29 million by $2050 .{ }^{54}$ That said, this has not translated into gender parity in the renewable energy workforce.

In 2018, a global survey in 144 countries found that women only represent $32 \%$ of full-time employees in the renewable energy field. ${ }^{55}$ This is significantly

\footnotetext{
51 USAID and IUCN, "Advancing Gender in the Environment: Making the Case for Gender Equality in Large-Scale Renewable Energy Infrastructure Development," AGENT Thematic Energy Brief Series, (2018), ss.

52 Fraune, C., "The Politics of Speeches, Votes and Deliberations: Gendered Legislating and Energy Policy-Making in Germany and the United States," [2016] 19, Energy Research \& Social Science, 134-41.

53 Ibid.

54 Ibid. No. 5

55 Ibid. No. 5.
} 
higher than the $22 \%$ average of women's workforce representation in the gas and oil industries, but considerably lower than the share of women employed in manufacturing, finance, education, health, social work and lower than average across the economy. ${ }^{56}$ The few women participating in the renewable energy sector are more likely to be employed in lower-paid, human resources, administrative and public relations positions, rather than on more technical and operational-oriented positions. ${ }^{57}$ Without counting cleaning, secretarial and administrative roles, the ratio of women's participation in the renewable energy workforce drops to $20 \% .^{58}$

However, even though women represent a small share of the workforce in the energy industry, their livelihoods are often dependent on the traditional energy industry in supportive roles in lower-paid services and informal work. ${ }^{59}$ Women thus tend to be left behind in energy transition programs as, for the most part, efforts to retrain and compensate fossil fuel workers are not aimed at women indirectly dependent on the fossil fuel industry. If targeted gender-transformative interventions are not implemented, existing patterns of gender segregation and discrimination in the traditional fossil-fuel workforce will continue to be replicated in the renewable energy system. ${ }^{60}$

Issues of participation tend to be different in decentralized renewable energy systems, in contrast to the dominant energy model driving the energy transition, which is highly centralized, capital intensive and large-scale. ${ }^{61}$ The decentralized form of off-grid renewable energy systems provides greater opportunities for developing energy solutions responsive to local and gender differentiated needs, providing energy access to communities living in poverty, and for engaging women in the management, generation and distribution of renewable energy solutions. ${ }^{62}$ In recent decades, women have made tremendous gains in small-scale and off-grid

\footnotetext{
56 Ibid. No. 5. See also: IEA, "Tracking Gender and the Clean Energy Transition, 2018, ss.

57 Ibid. No. 5.

58 GWNET, "Women for Sustainable Energy: Strategies to Foster Women's Talent for Transformational Change," 2020, ss.

59 Piggot, G., Boyland, M., et al., "Realizing a Just and Equitable Transition Away from Fossil Fuels," Stockholm Environment Institute, 2019, ss.

${ }^{60}$ HRC, "Women's Human Rights in the Changing World of Work," Report from the UN Working Group on Discrimination Against Women in Law and in Practice, 2020, UN Doc A/HRC/44/51.

61 For decades, power grids have been organized in centralized large-scale power generating plants connected via long transmission and distribution lines to provide electricity to end-users. Decentralized or distributed power systems are a relatively new approach whereby energy systems seek to put power sources closer to end-users by generating electricity though small-scale power plants.

62 IRENA, "Renewable Energy: A Gender Perspective" (2019), available at https://irena.org/-/media/ Files/IRENA/Agency/Publication/2019/Jan/IRENA_Gender_perspective_2019.pdf.
} 
decentralized renewable energy systems as installers, technicians, maintenance workers, small-scale business owners and household users. ${ }^{63}$

Women's participation in managing small-scale and decentralized renewable energy resources is facilitated by the fact these energy sources can be distributed. Solar and wind energy, energy conservation and efficiency, energy storage and demand response mechanisms can be found and developed locally in almost all world communities. These unique conditions provide the basis for women and communities at large to redefine their relationships with energy systems into a democratically owned and managed public good. ${ }^{64}$

The Special Rapporteur on Extreme Poverty and Human Rights highlighted that decentralized energy production has potential where large-scale on-grid energy infrastructure is not cost effective. ${ }^{65}$ These alternative forms of renewable energy generation and distribution also tend to have several co-benefits, such as the creation of new sources of income and greater local community participation, ensuring that the needs of low-income households are better considered in energy solutions. ${ }^{66}$

Due to its benefits, the decentralized renewable energy sector has made incredible progress over the last decades. For instance, through the 'Clean Energy for all Europeans Package', the European Union introduced the concept of "energy communities" in the legal corpus that regulates the energy system at the regional level. ${ }^{67}$ Energy communities are understood as a "way to 'organize' collective energy actions around open, democratic participation and governance and the provision of benefits for the members or the local community." 68 In this sense, energy communities can take different legal forms, namely a cooperative, an association, partnership, a non-for-profit or small/medium size business that enables citizens' active participation as producers, consumers, sellers or

\footnotetext{
${ }^{63}$ Energy Democracy, Introduction, ed. Denise Fairchild and Al Weinrub, Washington, DC: Island Press/ Center for Resource Economics, (2017) https://doi.org/10.5822/978-1-61091-852-7_1

${ }^{64}$ Energy Democracy, ed. Denise Fairchild and Al Weinrub, Washington, DC: Island Press/Center for Resource Economics, (2017) https://doi.org/10.5822/978-1-61091-852-7_1.

65 HRC, Report of the Special Rapporteur on Extreme Poverty and Human Rights, Olivier De Schutter (2020), UN Doc A/75/181/Rev.1.

${ }^{66}$ HRC, Report of the Special Rapporteur on Extreme Poverty and Human Rights, Olivier De Schutter (2020), UN Doc A/75/181/Rev.1.

67 European Commission, "Energy Communities," 2020, ss.

${ }^{68}$ Caramizaru, E. and Uihlein, A., "Energy Communities: An Overview of Energy and Social Innovation," EUR 30083 EN, Publications Office of the European Union, Luxembourg, 2020, ss.
} 
by providing flexibility through demand storage services. ${ }^{69}$ This innovation in energy policy through distributed green-energy is expected to advance energy efficiency in households and local businesses, fostering renewable energies and fighting energy poverty.

Between 2010 and 2017 more than 920 million people worldwide have been connected to electricity, 420 millions of which receive energy from decentralized renewable energy solutions. ${ }^{70}$ Although women's participation remains low in these energy arrangements, women-led micro and small-scale businesses comprise about $30 \%$ to $37 \%$ of total small enterprises in emerging markets. ${ }^{71}$ There is thus still untapped potential to further support decentralized forms of renewable energy production and distribution to propel women's engagement and decision-making power in the renewable energy workforce.

\section{Women's Participation in Productive Energy Uses}

Due to gender norms and social practices women are often associated with household activities and are the main users and suppliers of community and household energy. Worldwide women are seen as responsible for housework and caregiving, including energy gathering and provision in the home. With differences across countries and in types of fuel, women are often seen as responsible for collecting biomass (e.g., firewood, dung, crop waste and charcoal) for cooking and heating, especially in low socio-economic contexts. As households living in poverty are more dependent on these sources of energy than households with higher levels of income, improvised women also spend more time collecting biomass for cooking and heating and are more heavily reliant on kerosene lamps, candles and batteries for lighting. ${ }^{72}$ The lack of access to safe, sustainable, and reliable sources of energy thus highly increases the drudgery of housework and caregiving women usually perform. As a result, care burdens give rise to chronic time deficits, which preclude women and girls from exercising their fundamental rights to education, work and health, as well as their access to lei-

\footnotetext{
69 Ibid. No. 33.

70 Alliance for Rural Electrification and GET.invest, "Women Entrepreneurs as Key Drivers in the Decentralised Renewable Energy Sector: Best Practices and Innovative Business Models," 2020, ss.

71 Ibid.

72 Rewald, R., "Energy and Women and Girls: Analyzing the Needs, Uses, and Impacts of Energy on Women and Girls in the Developing World," Oxfam Research Backgrounder series, Oxfam America, (2017), ss.
} 
sure and self-improvement. All of which are essential to increase women's and communities' standards of living.

Women's participation in energy through biomass provision also has negative implications for their health. Household air pollution caused by biomass combustion and its effects on health are well documented. ${ }^{73}$ Annually close to four million people die prematurely from illnesses attributable to household air pollution, such as pneumonia, lung cancer and chronic respiratory diseases from biomass combustion paired with kerosene. ${ }^{74}$ At least $60 \%$ of all these premature deaths occur in women and girls, who, due to their caregiving roles, spend more time exposed to household air pollutants. ${ }^{75}$

Furthermore, it is frequently assumed women have control over decisions at the household level, but this is often not the case. Women tend to be responsible for gathering household energy, but men are commonly the main decision-makers when energy and electrical appliances must be acquired. ${ }^{76} \mathrm{~A}$ study in Zimbabwe found that women had a hard time accessing solar cookers because technology and its development is seen as a male prerogative. ${ }^{77}$ Thus, critical decisions on how to spend economic resources and which technological devices to buy is a highly gendered issue. Women's participation as users of key energy resources and appliances is shaped and restricted by gendered intra-family dynamics. ${ }^{78}$

Going beyond women's role as energy users and providers on the household level, women also participate in other essential productive activities that involve different energy uses. Agriculture is an energy-intensive sector where about $80 \%$ of the food produced worldwide is produced by women on smallscale farms. ${ }^{79}$ Despite women's vital contribution to income generating activities and local and global supply chains of essential goods and services, traditionally women have had less access to energy and electrical appliances need-

\footnotetext{
73 UNEP, "Seven Things You Should Know About Household Air Pollution," 2021, ss.

74 Von Schirnding, Y., Bruce, N. et al., "Addressing the Impact of Household Energy and Indoor Air Pollution on the Health of the Poor: Implications for Policy Action and Intervention Measures," Paper prepared for the Commission on Macroeconomics and Health, Energia, 2015; See also: World Health Organization (WHO), "Household Air Pollution and Health," 2021, ss.

75 Ibid. No. 88

76 Kooijman, A., Corry, J. and Ireri, M. "The Role of Appliances in Achieving Gender Equality and Energy Access for All, Policy Brief \#4 Energia', 2020; Ibid. No.88

77 Clancy, J., "Household Energy and Gender: An Introduction," Sparknet, 2002, ss.

78 Ibid.

79 Oxfam, "Empowering Women Farmers to End Hunger and Poverty," 2021, ss.
} 
ed for productive activities' mechanization. This lack of power over automated production compels many women to perform economic activities with low productivity levels, precarious working conditions and excessive drudgery. ${ }^{80}$ Women's participation in decision making on how energy resources and technology are used remains a key factor to ensuring women engage on an equal footing with men in key economic activities.

Gender dynamics related to energy and technology use are not resolved only by providing access to these resources and tools. There are risks that renewable energy interventions will further exacerbate gender inequalities if they do not fully integrate a gender lens and an intersectional rights-based participatory approach. When attempts have been made to provide access to sustainable energy sources and improved techniques or technologies, the result is often that men take over women's economic activities. For instance, in Sri Lanka and Bangladesh traditional rice-milling which involved onerous labor-intensive work mostly performed by women at a very low remuneration level, was replaced by mechanized milling that currently mostly men do. ${ }^{81}$ For many women this flip on traditional gender roles represented a loss of income and an unfortunate return to unpaid domestic and care work at the household level. ${ }^{82}$

\section{Women's Participation in Climate and Energy Finance}

The overall investments in the energy transition and in energy access at the local, national, and international levels are not flowing toward sustainable energy solutions that promote women's participation in the energy sector. Internationally, development finance has mostly remained within the fossil fuel sector, locking countries into decades of harmful greenhouse gas emissions and risk of stranded assets. ${ }^{83}$ Despite the increased awareness of gender concerns in energy and climate change solutions, the resources directed to energy projects incorporating gender equality objectives and enhancing women's participation

\footnotetext{
80 Jha, S., Jain, T. and Patnaik, S., "Improving Women's Productivity and Incomes Through Clean Energy in India," CEEW, Shell Foundation \& UK Foundation, 2021, ss.

81 Cecelski, E., The Role of Women in Sustainable Energy Development, National Renewable Energy Laboratory, 2000, ss.

82 Ibid.

83 Seforall, "Energizing Finance: Understanding the Landscape 2020: Main Findings," Energizing Finance Research Series, Seforall and Climate Policy Initiative, 2020, ss.
} 
remain very low, at only $9 \%$ of all energy sector development finance. ${ }^{84}$ The current finance architecture at all levels commonly privilege funding towards expansive, large-scale high-tech infrastructure projects and fail to consider the many advantages of distributed community-led projects focused on women's participation. ${ }^{85}$

Furthermore, at the national level, States too often fail to incorporate gender perspective into fiscal policies and energy budgeting that is critical to invest in gender-responsive energy systems. At the local level, access to credit and other forms of loans is also a principal barrier limiting women's participation in the provision of safe, sustainable and modern energy solutions.

Despite these global trends, the Green Climate Fund (GCF) has made progress by adopting a Gender Policy and Action Plan 2020-2023 that has promoted a greater focus on women's participation in energy transition processes. Since 2018, all projects approved by this entity on record have a gender plan that focuses on women's participation and gender-equality concerns in energy policy and project development. ${ }^{86}$ To scale up these efforts, policies to mainstream gender in finance and budgeting should be implemented at the international, national, and local level to facilitate women's participation in the energy transition.

\section{Women's Participation in Urban Planning and Development}

Currently, cities contribute $71-76 \%$ of all energy-related greenhouse gases driving the climate emergency. ${ }^{87}$ Thus, sustainable and gender-transformative urban planning and policy making is critical to ensure a just transition to low carbon societies. ${ }^{88}$ However, women's participation in these key decision-making spaces and gender-sensitive responses to urban planning and climate policy is still absent in most urban areas. The representation gender gap at government agencies and scant access to public facilities and public services is significantly apparent at the local level. Male-dominated sectors such as transportation and

\footnotetext{
84 Ibid.

${ }^{85}$ European Capacity Building Initiative, Pocket Guide to Gender Equality Under the UNFCCC, 2020, ss.

86 Ibid.

87 Alber, Gotelind and Cahoon, Kate, "Chapter 5: Into the Cities: Developing and Supporting Resilient, Sustainable and Gender-Responsive Urban Environments" in Aguilar, L., Granat, M, and Owren C. (eds), Roots for the Future, IUCN, 2015, ss.

88 Ibid.
} 
energy continue to neglect women's needs, concerns and capabilities. According to a report from United Cities and Local Governments, women make up less than $5 \%$ of mayors and $20 \%$ of city councilors worldwide. ${ }^{89}$ Energy poverty, which disproportionately affects women, is also a reality in urban areas. In some European countries, up to $30 \%$ of the population suffers from energy poverty, unable to lay hands on sufficient heating fuel to maintain a decent indoor temperature. ${ }^{90}$ In cities in both the Global North and South, many women in impoverished and informal urban communities rely on biomass for cooking, lighting and heating. ${ }^{91}$

Women's participation in local city government actions is key to addressing these challenges and taking advantage of opportunities that arise from the energy transition. Local authorities are closest to citizens placing them in a better position to integrate gender and human rights issues according to local needs in policymaking, including fostering a rights-aligned approach to the participation of women in energy policies and projects related to public lighting, transport and housing. ${ }^{92}$ These comprehensive strategies to transform energy systems are especially relevant considering that populations continue to shift toward urban centers, expanding urban sprawl and leaving marginalized populations, including low-income women, away from key decision-making spaces.

\footnotetext{
89 Ibid. See also: "United Cities and Local Governments" (UCLG) Women. (n.d.). The equality agenda of United Cities and Local Governments, ss.

90 Ibid. no. 104

91 Živčič, Lidija, González-Pijuan, Irene, et al., Combating Energy Poverty with Gender-Just Policies, in Why the European Green New Deal Needs Ecofeminism: Moving from Gender-Blind to Gender-Transformative Environmental Policies, European Environmental Bureau and Women Engage for a Common Future, 2021, ss.

92 Ibid. no. 104.
} 

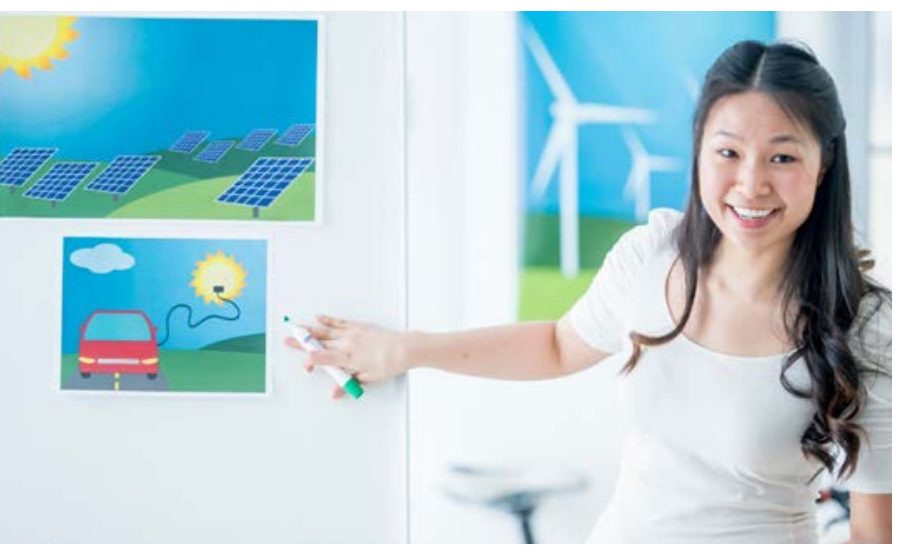

Recommendations to Advance Women's Participation in the Energy Transition

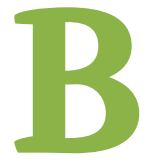

uilding on the analysis above, this section seeks to provide practical advice to States and other stakeholders on how to operationalize women's right to participation in the transformation towards gender-just energy systems. We must consider, however, that participation is always embedded in specific sociocultural contexts and power dynamics, and one cannot formulate universal guidelines. ${ }^{93}$ Appropriate policies and measures are context dependent and should be developed through a bottom-up approach, in close consultation with communities and rights-holders. ${ }^{94}$ With this caveat in mind, it is nevertheless possible to propose standards for rights-based participatory mechanisms or processes that facilitate women's meaningful participation at all levels of decision-making in the energy transition.

The following policy recommendations also provide a case study or promising practice to illustrate how measures may be implemented in practice. Different partner organizations working on the ground with communities and rights-holders in several countries across the world have provided the information for these case studies.

\section{Legal Framework and Accountability}

\section{Ensure Gender Equality in Legal and Institutional Energy Frameworks}

States' commitment to undertake gender progressive policies and protect women's rights in energy legal and institutional frameworks will bolster the bargaining power women have in relation to their communities, families and the State itself, enabling them to overcome barriers to participation. Likewise, legal and institutional

\footnotetext{
93 HRC, Report of the Special Rapporteur on Extreme Poverty and Human Rights, Magdalena Sepúlveda Carmona, 2013, A/HRC/23/36, paragraph 19.

94 Ibid.
} 
frameworks can play a key role in determining property status, educational levels, and the extent to which the rules that govern membership in a given program are discriminatory (both when set up by the State or another actor). Legal and institutional energy frameworks should explicitly include principles of non-discrimination, gender equality and the right of women to participate on an equal footing with men across the energy sector. Ensuring gender equality in legal and institutional frameworks involves a variety of measures, including:

- Explicitly obliging policymakers and public officials-actively, in good faith and with an intersectional perspective - to seek and support the meaningful participation of women in all spheres of the energy transition.

- Putting operational guidelines and policies in place, as well as providing capacity-building so public officials can implement these laws; as well as for corporate actors to facilitate their implementation, an assurance that they are adaptable to different contexts and will allow innovation based on feedback women provided in all their diversity.

- Strengthening and enforcing minimum standards for participatory processes, including thresholds and specific standards that demand differentiated gender needs and concerns. 

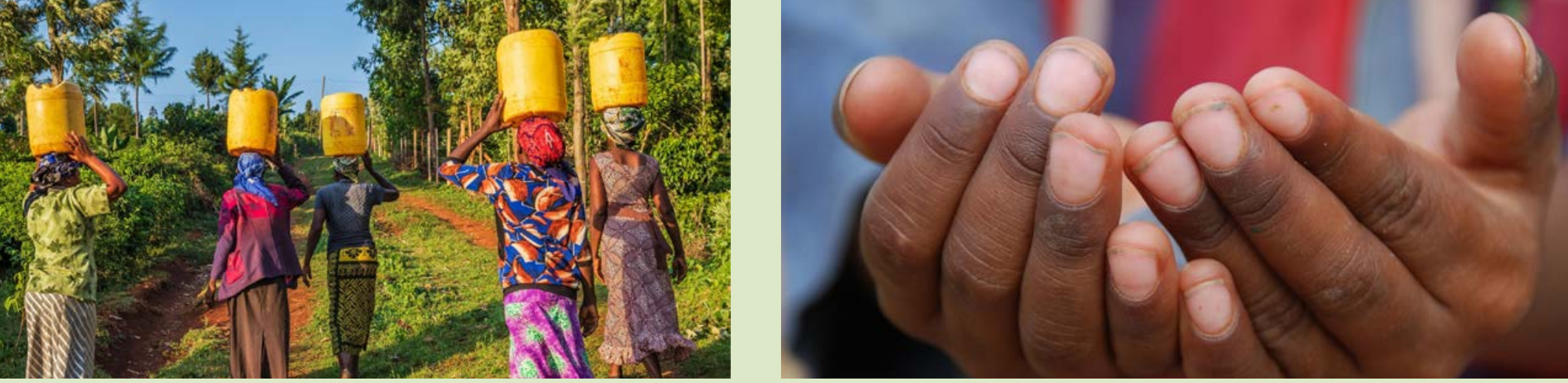

\section{CASE STUDY:}

\section{The Kenya Government's "Gender Policy in Energy"}

In 2019 Kenya's Ministry of Energy launched the "Gender Policy in Energy" to mainstream a gender lens in the national energy legal and institutional framework and ensure energy services honor constitutional rights on substantive gender equality. It is the first policy of its kind in Africa. The policy provides a framework to incorporate gender perspective in all energy policies, programs and projects by:

- Recognizing that mainstreaming gender in the energy sector is a key measure for complying with constitutional rights related to gender equality.

- Strengthening frameworks to enhance women's participation in the energy workforce.

- Increasing gender awareness across the energy sector.

- Promoting clean cooking solutions and the principle of environmental sustainability, including a strong focus on implementing renewable energy solutions.

- Integrating gender consideration in energy monitoring and evaluation.
The policy establishes commitments and strategies to ensure gender's sustainable mainstreaming at all levels and phases throughout the national energy sector. Its rationale and guiding principles also highlight a critical need to promote women's participation and address gender imbalances in access, benefit sharing and decision-making, to create an enabling policy framework that advances a rights-based approach to women's participation in the energy transition.

Sources: Kenyan Ministry of Energy, Gender Policy, (2019), available at: https://energy.go.ke/wp-content/ uploads/2019/10/Gender-Policy-in-Energy.pdf Also see: Energia, Gender and Energy Country Briefs: Kenya, (2020), available at: https://www.energia.org/ assets/2021/02/Country-brief-Kenya_Nov2020_final.pdf 


\section{Business Enterprise's Human Rights Obligations}

Corporate actors have a primary role in the energy transition. In 2019, about $86 \%$ of all recorded investments in the renewable energy sector came from private finance..$^{95}$ In this context, to ensure corporate actors comply with international human rights and environmental standards, States have a positive obligation to regulate them and ensure their activities do not encroach upon fundamental rights, including the right to participation. ${ }^{96}$ Among other measures, this obligation involves requiring companies to adopt due diligence policies, conduct gender-sensitive impact assessments and consultation processes when relevant, ensure gender diversity in their workforce at all decision-making levels and protect social movements, communities and human rights defenders who oppose specific energy policies and projects from potential retaliation at the hands of corporate actors. ${ }^{97}$ The States' duty to regulate the activities of private actors should also address business-related human rights impacts to the right to participation throughout the energy supply chain and in all territories under their jurisdiction.

\footnotetext{
95 IRENA and Climate Policy Initiative (CPI), "Global Landscape of Renewable Energy Finance," 2020, ss.

96 UN Guiding Principles on Business and Human Rights, "Implementing the United Nations 'Protect, Respect and Remedy' Framework," 2011.

97 OHCHR, "Human Rights, Climate Change and Business: Key Messages," 2020, ss.
} 


\section{CASE STUDY:}

\section{Making the "Duty of Vigilance Act" in France a Reality}

In 2017, France adopted the "Duty of Vigilance Act," 98 imposing a legal obligation on certain multinationals to establish, effectively implement and publish "reasonable vigilance measures" adequate to identifying risks and preventing severe impacts on human rights and fundamental freedoms, on the health and safety of individuals and on the environment. The law foresees that companies based in France that either have 5000 employees in France or 10,000 employees worldwide (including their direct and indirect subsidiaries) establish, implement, and publish a vigilance plan for human rights, health, security, and environment. It targets the parent company, its subsidiaries, suppliers, and contractors and is the first law worldwide to attempt lifting the corporate veil. The legislation is largely based on the UN Guiding Principles on Human Rights and it allows victims of any violation in the above-mentioned categories to seek justice before French courts.

ProDESC, a Mexican human rights notfor-profit organization, is legally representing Unión Hidalgo, an Indigenous Zapoteca community located on the Isthmus of Tehuantepec

98 Law No. 2017-399 of 27 March 2017, available at https:/ /www.legifrance.gouv.fr/jorf/id/JORFTEXT000034290626 in far-southern Mexico. The region has suffered from the adverse impacts of constructing several large-scale wind farms in their territory. Therefore, under the Duty of Vigilance Act, the community has sued Electricité de France (EDF), a French multinational electric utility company to demand the suspension of the construction of a large wind farm, the Gunaa Sicarú Wind Power Park project, in their territory, until it complies with its human rights obligations. EDF is considered responsible for committing violations against the rights of the Indigenous population's right to free, prior and informed consent, as well as for fostering attacks against human rights defenders during the wind park's construction. The Duty of Vigilance Act has provided an opportunity for the Unión Hidalgo community to seek redress under the French jurisdiction after Mexican authorities and EDF have failed to respond to the community's demands.

Despite the challenges associated to the implementation of this landmark legislation, the Duty of Vigilance Act remains a key step forward in the regulation of corporate actors throughout global supply chains and may play a key role in ensuring business activities avoid negative human rights implications. 


\section{Ensuring Accountability in Energy-Related Participatory Processes}

Measures to encourage women's participation and the establishment of participatory processes in the context of the energy transition need to be subjected to oversight and accountability mechanisms to ensure they comply with their intended purposes. In that sense, States and other relevant stakeholders driving the energy transition must implement a series of measures including:

- Instituting effective monitoring and evaluation systems for participatory processes to ensure women's involvement-in all its diversity—in the process.

- Using gender-disaggregated indicators and data to regularly monitor, report on and review gender-targets.

- Providing an accessible way for the public to hold public officials and corporate actors accountable for violations of women's right to participation, as well as for any abuse committed during participatory processes, including by incorporating an impartial, accessible and confidential complaint or grievance mechanism in participatory procedures.

- Ensuring the judiciary and law enforcement system is well trained, has sufficient resources and is able to enhance judicial oversight and prosecute any encroachment upon women's right to participation, as well as the interrelated rights to freedom of expression and rights to assembly and association.

\section{Data Collection, Access to Information and Transparency}

\section{Collect Gender Disaggregated Data}

Most gender disaggregated data available in the energy sector is focused on women's participation as energy users at the household level and gendered negative consequences of energy poverty. Empirical evidence on women's participation at macro-level energy policy decision-making and as participants in different roles throughout the energy supply chain is scarce. Studies do not provide data on the impacts of diverse energy policies and projects or how they affect women's livelihoods, gender roles and relations. ${ }^{99}$ The same is true of gender

99 Feenstra, M. and Özerol, G., "Energy Justice as a Searchlight for Gender-Energy Nexus: Towards a Conceptual Framework," 2021, 138, Renewable and Sustainable Energy Reviews. 
disaggregated data on energy uses beyond the household level in energy-intensive economic activities, such as agriculture, food production, services and manufacturing. ${ }^{100}$

States and other stakeholders should develop and compile gender disaggregated data with an intersectional lens to adequately consider the full scope of gendered impacts in energy transition policies and projects, as well as women's role in the development, design, adaptation and use of renewable energy technologies beyond the household level. This would permit identifying potential barriers that limit women's right to participate in the energy sector and to make informed decisions while planning and implementing energy transition policies and projects.

\section{Ensure Transparency and Access to Information}

Transparency and access to information is crucial if women are to participate at all levels of the transition to new, sustainable and more equal energy systems. States and corporate actors leading renewable energy policies, programs and projects should provide timely, sufficient and objective data to the public, in accessible formats and via appropriate channels, to be able to participate in decision-making. To be effective, these efforts must consider gender differentiated needs, technical understandings, communication channels, literacy levels, and native languages of the rights-holders specifically affected by these measures.

States must require prompt public notification of reasoned decisions related to energy programs, policies and projects; then publish the content of the relevant social and environmental impact assessments that were conducted to evaluate these energy interventions' potential risks. This is particularly important in the context of the energy transition, where public information on energy policies and projects is rarely made available, and, when it is, it is usually disseminated using highly technical language that makes it inaccessible to most members of the public. The pervasive lack of transparency and access to available energy sector information is one of the main issues preventing women's engagement in debates on energy justice and energy transitions.

100 Ibid. 


\section{CASE STUDY:}

\section{Toward a Gendered Digital Platform for Energy in Mexico}

Currently, Mexico has an installed clean energy capacity of $29.5 \%$, with $17 \%$ from hydroelectric sources, $4 \%$ from solar energy and $7 \%$ from wind power. In 2016, Mexico joined 155 other signatory countries that signed the Paris Agreement committing to a $25 \%$ reduction in greenhouse gas emissions. In this line, the Mexican government has made efforts to foster transparency in the energy sector and the main institutions that determine the country's energy policy have a wealth of open data, including extensive information on their internal functioning, in an online 'National Transparency Platform.' But in reality, only a few people, mainly experts and key decision-makers, can understand this information and know where to find relevant information, how to interpret it and its implications for everyday life.

Ombudsman Energy Mexico (OEM) is a civil society organization founded in 2015. It seeks recognition of "energy access" as a human right, that strives for an energy sector that respects human rights and takes on climate change. OEM is currently working on creating a public, online platform where information regarding the energy sector, energy producers and sources, infrastructure, accessibility, prices, etc., can be centralized. The organization wants to facilitate updating processes and enabling participation for those involved in energy production, distribution and consumption. The digital platform OEM developed also seeks to materialize "substantive transparency" to facilitate citizen consultations and foster the transparency and accessibility of energy sector information. The platform will furthermore foster coordination and discussion between organizations seeking to monitor Mexico's energy transition.

OEM considers that energy sector information democratization can lead to the democratization of the sector itself, increasing capacity for individuals' actions, especially those belonging to traditionally marginalized sectors, such as women and communities impacted by energy projects. Access to information through this initiative is critical to highlight the human rights dimension of the energy sector.

Note: This case study was provided by Ombudsman Energy Mexico.

https://oem.org.mx/ 


\section{Education, Training and Employment}

\section{Combat Harmful Gender Roles and Stereotypes}

Research shows that gender roles and social perceptions-such as those concerning women's ability to make meaningful contributions-is a deep-rooted determinant of women's participation in each social domain. If women internalize these perceptions, which is often the case, they may self-censor their options and efforts to change these discriminatory practices. ${ }^{101}$ To enhance women's participation in traditionally male-dominated spheres, such as the energy sector, it is necessary to alter both how women perceive themselves and how the State, families and communities perceive women, in order to change harmful social practices and norms that exclude women from participating in energy.

101 Bina, Agarwal, "Participatory Exclusions, Community Forestry and Gender: An Analysis for South Asia and a Conceptual Framework," World Development 29, no. 10 (October 2001): 1623-48, https://doi.org/10.1016/S0305-750X(01)00066-3. 

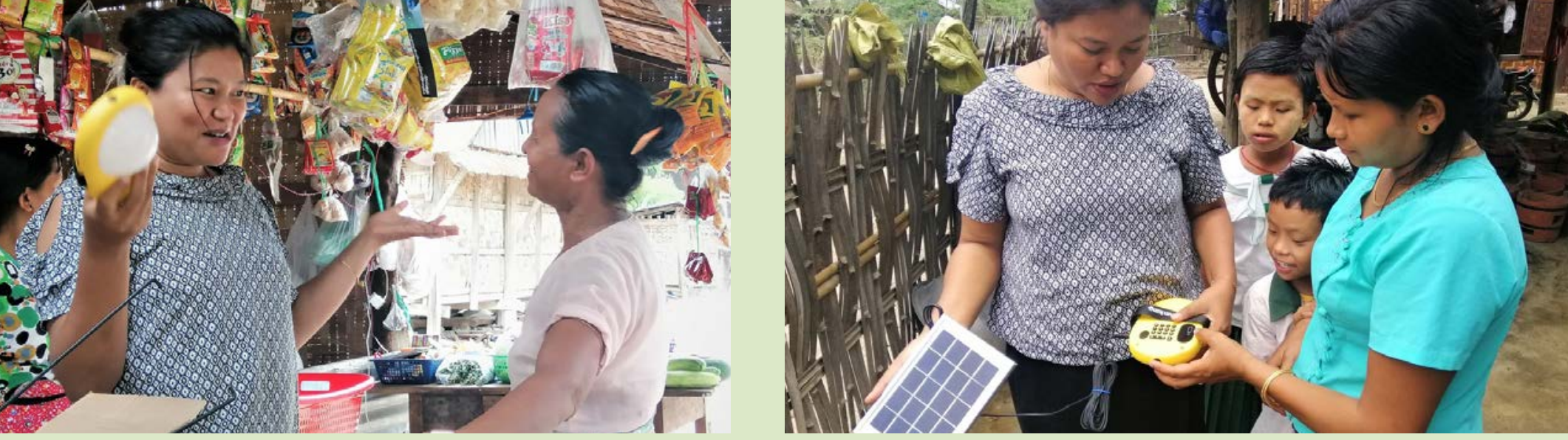

CASE STUDY:

\section{Combating Gender Stereotypes in Myanmar's Energy Transition}

Myanmar is one of the countries most affected by climate change, situated at high risk from natural disasters like floods, cyclones, earthquakes and droughts. Rural populations' lack of access to modern quality energy and to sustainable energy solutions increases their vulnerability and severely constrains their socio-economic development. Around $80 \%$ of Burmese households cook with wood on traditional fireplaces, putting great pressure on forest resources contributing to a $2 \%$ annual deforestation. Biomass use as the main source of energy is also responsible for backbreaking work women are expected to do, as well as for respiratory diseases linked to exposure to harmful fumes.

Geres, a development civil society organization working in Europe, Africa and Asia to improve living conditions and fight climate change, launched the Rural Energy Access to
Communities and Households (REACH) project in rural areas of the central Myanmar Dry Zone in 2018, following participatory workshops with communities and women's networks. The Dry Zone, home to $30 \%$ of the country's households, has scant coverage from the national power grid, though the government is currently pushing for its expansion.

As acknowledged by the International Labor Organization, major challenges Burmese women entrepreneurs face include gender norms concerning women's role in society, lack of respect for women as entrepreneurs and a consequent limited access to resources, family support and life-work balance, as well as few links to supply chains and limited availability to gender sensitive services that could be responsive to their needs.

To combat pervasive gender roles, as part of the REACH program, Geres provided 
training and coaching throughout the project to give women community members the confidence and space to participate in the development of sustainable energy solutions. They received three days of training on how to sell solar kits (primarily lamps and domestic systems) as well as improved stoves. At first, some women did not feel confident speaking, since it is usually men who participate in village meetings as household heads. Thus, Geres organized a monthly meeting that gathered women entrepreneurs to share experiences and provide peer-to-peer support. Following COVID-19's confinement measures, social media platforms were used for women to continue sharing their success stories, inspire others and stay in touch about challenges and struggles. These networking opportunities were considered by women community members as valuable spaces to build capacities and long-standing relationships, as normally women do not have the opportunity to interact and exchange views on the development of economic activities in other spaces (e.g., markets and tea shops) as men often do.

During the training, women strongly expressed their interest in learning to make minor repairs to energy products and appliances, ensuring goodwill after closing sales with their customers. This has demonstrated to other community members that when women have access to information and training, they have the same ability as men to perform tasks generally envisioned as a "men's work", thus slowly changing gender norms and stereotypes that limit women's participation the provision of energy solutions.

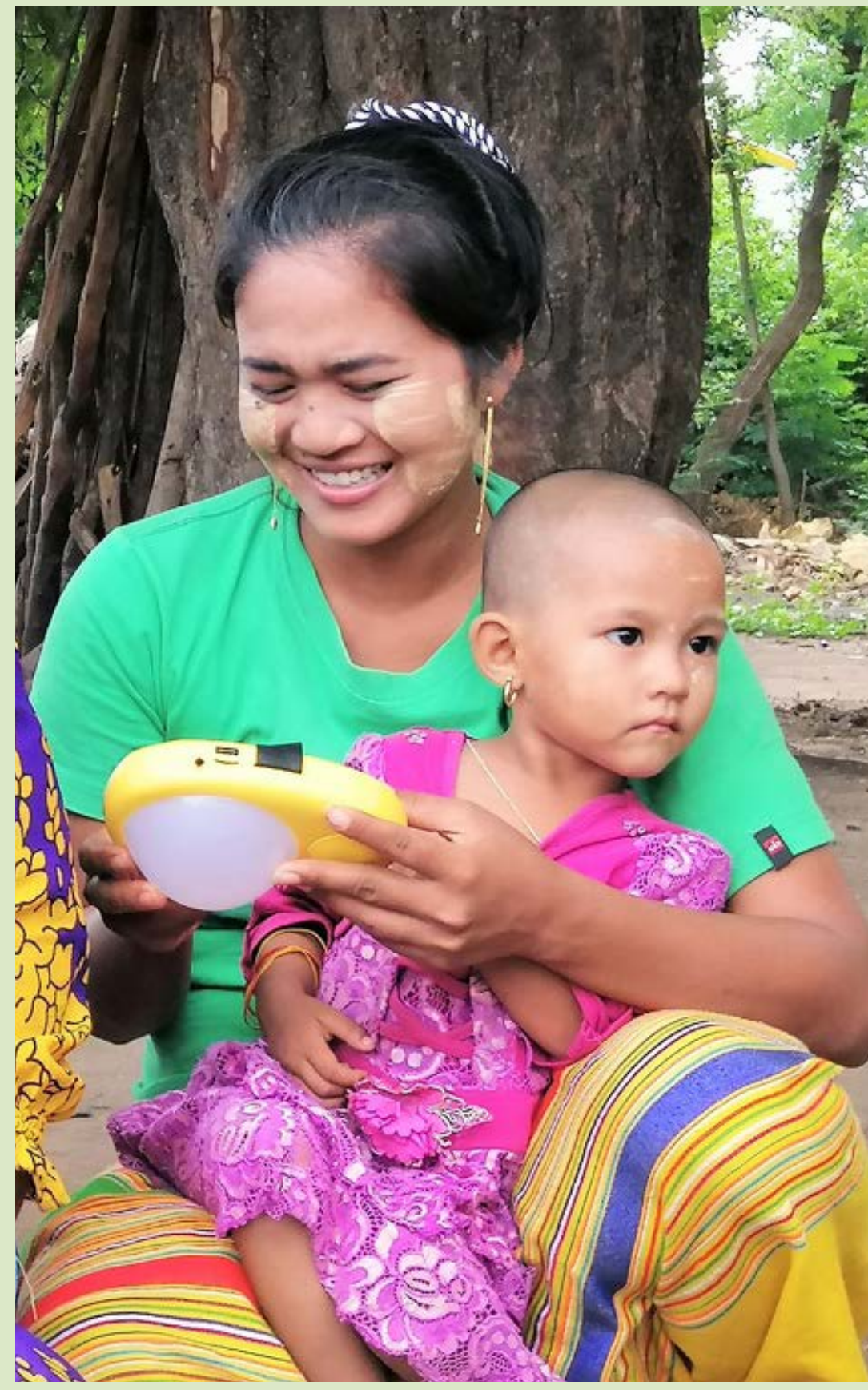

Geres believes challenging stereotypical views is a positive approach for changing perceptions and revaluing women's longterm contribution to their community. These activities have slowly changed how women perceive themselves, expanding their view 


\section{Provide Training and Education for Women's}

\section{Participation in the Energy Sector}

States and relevant stakeholders driving the energy transition must improve the quality of education and training services to ensure women develop the necessary skills and talent to participate in the energy sector. This should start in early education stages and move through women's life cycles.

One way to achieve this would be to fund specific programs targeted at increasing women and girls' participation in education in areas relevant to the energy sector in science, technology, engineering and math (the "STEM" subjects and courses). We also need to transform and modernize education systems to reinforce positive messages for girls about their abilities in these fields as well as accelerate actions to achieve gender equality in innovation and technology development. Note the focus on STEM is not sufficient to achieve all aims; education and training programs need to envisage a more holistic approach to ensure women, particularly those without formal education and from low-income backgrounds, can also actively engage and participate in different roles. ${ }^{102}$ Other forms of informal training and skills development, such as mentorship programs and peer-to-peer training can play a leading role to foster women's participation in the global energy transformation.

Moreover, efforts need to be focused on advancing public education and training campaigns at the community level, to identify local needs and design programs to further develop women's capabilities as managers, technicians and renewable energy solutions developers, including when it comes to increasing energy efficiency. ${ }^{103}$

\section{Remove Barriers and Promote Employment Opportunities in Renewable Energy}

In order to make energy transition inclusive and just, barriers to women's employment at all levels of the renewable energy sector must be removed. Ways to achieve this include:

- Reducing bias by designing gender-sensitive recruitment processes.

- Enacting regulation to avoid gender pay gaps.

102 Nagel, J., Gender and Climate Change: Impacts, Science and Policy, Routledge, 2016, pp. 197-198

103 United Nations Framework Convention on Climate Change (UNFCCC), "Decision 3/CP.23: Establishment of a Gender Action Plan," 2017, UN Doc FCCC/CP/2017/11/Add.1 
- Establishing gender quotas and targets, including specific measures to ensure that women are equally represented in technical and leadership roles.

- Ensuring a more flexible and supportive working environment for a better work/life balance.

- Providing access to quality childcare, disability and senior care services.

- Combating sexual harassment and other forms of sexual and gender-based violence in the workplace.

- Ensuring equal and equitable opportunities for professional advancement.

- Challenging gender stereotypes by strengthening the visibility of women working in the renewable energy sector in different roles as top-level mangers, technicians, managers, administrators. And not least of all, supporting women-led renewable energy and energy-efficiency projects as well as networks at all levels of employment.

- Ensuring women who earned money, directly or indirectly related to the fossil fuel industry, have access to re-training and compensation schemes to transition to new employment opportunities.

Careful attention needs to be placed on initiatives fostering women's entrepreneurship as managers and owners of renewable energy micro-businesses. Even though these initiatives can provide opportunities for women to take a more prominent role in decision-making, fostering entrepreneurship programs may also have the unintended effect of subjecting them to indebtedness and financial risk, without any security mechanism to avoid falling into poverty if the business fails. Safeguards and access to social protection should be put into place to advance a gender-just energy transition framework. 

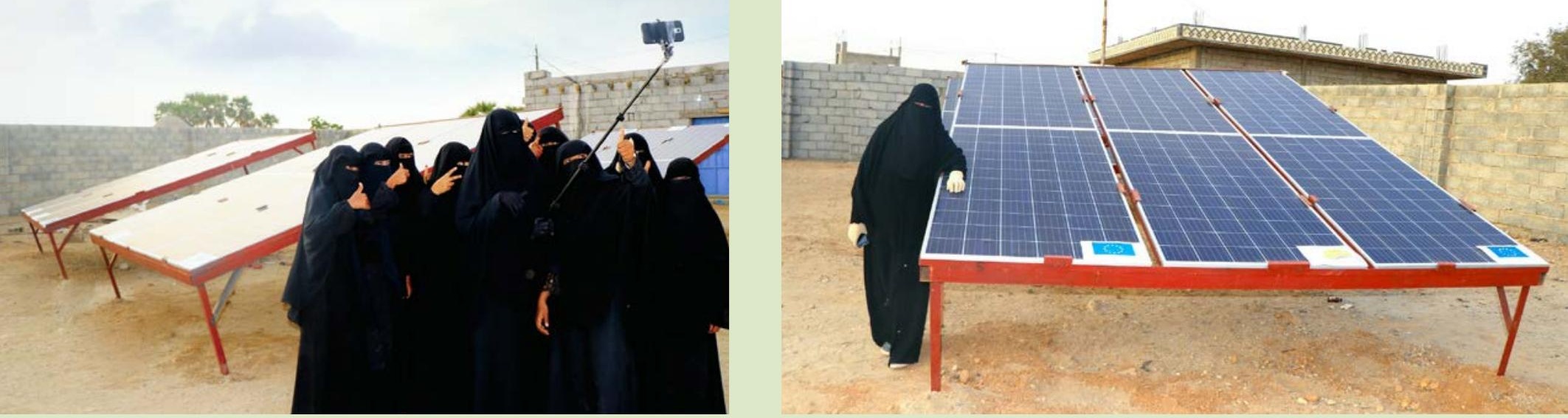

CASE STUDY:

\section{Yemen Offers Women Employment Opportunities as Solar Grid Managers and Operators}

In Yemen fossil fuel prices skyrocketed beyond most consumers' economic reach. Prior to the current armed conflict and humanitarian crisis, 20 liters of diesel cost $\$ 7$ USD but it has now reached a $\$ 17$ USD peak. Diesel is, therefore, not easily attained in national markets and service stations across the country. Solar microgrids are an alternative energy source which has given hope to local communities as they access clean, low-cost energy. Due to its affordability and the possibility of installation in remote communities, these renewable energy sources could be expanded to a large degree to provide for sustainable energy solutions and reduce energy poverty in the country.

The Sustainable Development Foundation (SDF), a Yemeni non-governmental development organization, is implementing the "Enhancing Rural Resilience in Yemen" (ERRY I) intervention to improve lives in local communities by installing solar energy systems and training women and young people to take on employment opportunities as solar energy microgrid managers and operators.

As part of the ERRY Joint Program, SDF supported 20 entrepreneurs (10 female and 10 male) as they established a micro-solar grid to provide sustainable energy to their local communities. The target beneficiaries coming from low-income households receive basic and advanced solar micro-businesses training in close collaboration with the staff of the International Labor Organization. The women and young people who graduate from the course acquire knowledge and skills to develop two different types of micro-business proposals; 1) community shops for providing affordable solar items such as lanterns, charging equipment, operational and maintenance toolkits, and 2) building a solar micro-grid to provide electricity to households and local businesses with limited or no access to electricity.

For the program's implementation, SDF has facilitated what they call the " $3 \times 6$ approach" where the community decides on alternative 
livelihoods that will generate employment and offer decent income earning opportunities. The community selects beneficiaries based on previously established vulnerability criteria and the list of selected candidates is made publicly available to ensure transparency. The selected beneficiaries then receive emergency employment incentives through the conditional "Cash for Work" program, where they start creating community projects, such as street cleaning, rehabilitating agricultural lands, terraces, etc. When collecting their wages, SDF releases only $50 \%$ to the beneficiaries and the other half stays in the bank as savings to cover solar energy business overhead.

The solar microgrid that SDF has helped developed through this program is the first enterprise of its kind run by Yemeni women and young people. The new solar microgrid has brought down the market price of electricity by $80 \%$ and most of the households and shops connected to it now have uninterrupted electricity 10 to 12 hours a day. This distributed solar system has, among other things, allowed marginalized Yemeni women and young people benefit from a source of income to cover their daily needs despite the current humanitarian crisis in the country.

The solar microgrid is a major instrument for engaging women in business activities that foster their skills development and economic independence. This has helped knock down barriers women usually face when they enter the workforce and receive an income in a social context where acceptance of women's participation in paid employment is still very limited due to traditional gender roles and social practices.

Note: Case study provided by SDF Yemen. http://sdf-yemen.org/
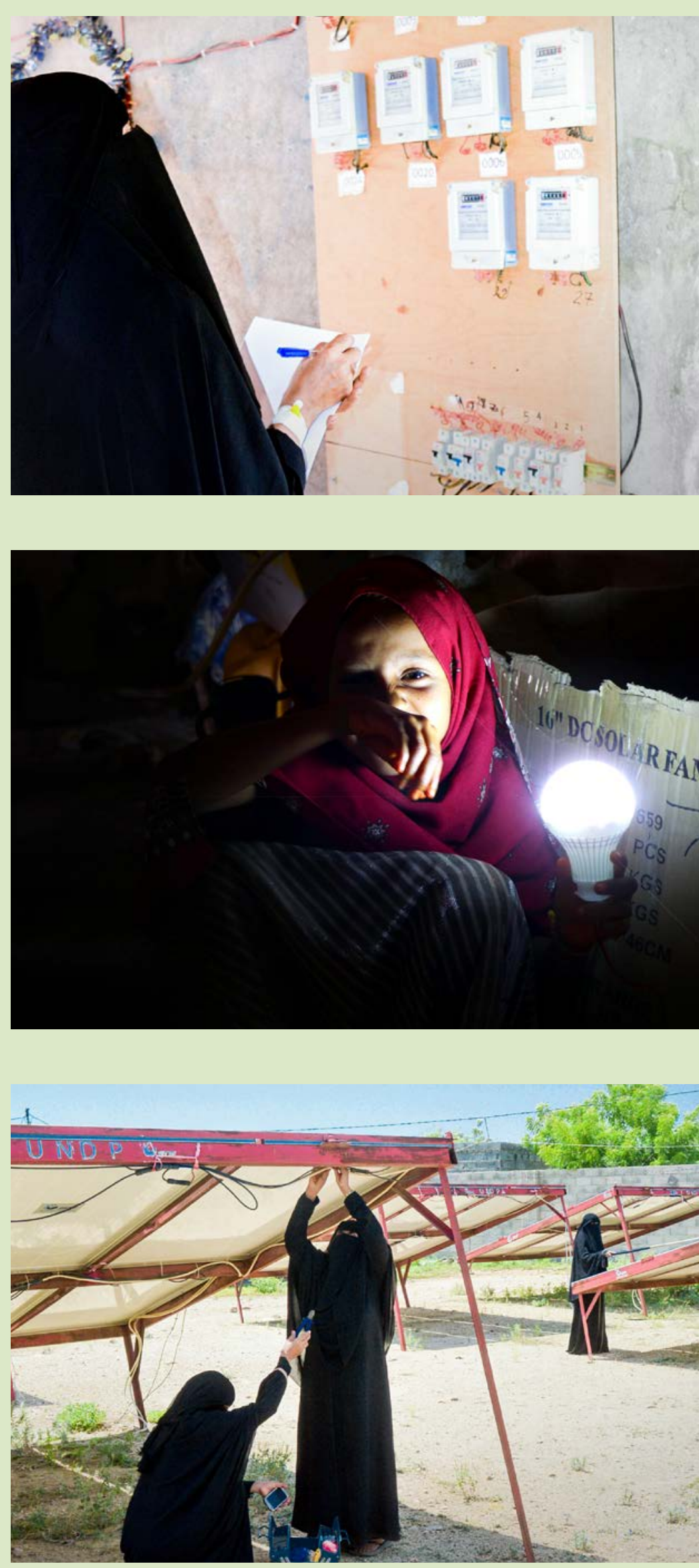


\section{Access to Universal Sustainable Energy and Appliances}

\section{Alternative Renewable Energy Sources and Electrical Appliances}

To ensure women participate in productive energy uses, it is essential to provide universal access to safe, reliable and sustainable energy sources to communities currently living in energy poverty. That said, large-scale energy projects are not always the most viable or cost-effective means of providing access to electricity in remote, low-income communities. Fostering different forms of decentralized, locally owned and community-led renewable energy systems can often better ensure universal access while providing additional co-benefits such as enhancement of democratic governance and local women's participation as managers, owners and renewable energy solutions providers.

In addition, relevant stakeholders should adopt a holistic approach to sustainable energy access by not only ensuring sustainable energy sources provision but also acquisition and use of energy efficient electrical appliances able to transform the energy into productive energy services (e.g., clean cooking stoves, lights, fans, mills, water pumps, refrigerators, washing machines, etc.). Electrical appliances are critical to empower women as energy users, as well as to facilitate women's participation in income generating activities.

To ensure women have the conditions to meaningfully participate on household and other productive energy uses, States should consider:

- Fostering investments in community-led and locally owned distributed energy systems that promote women's participation in the management, ownership and delivery of renewable energy solutions as a key means to reduce gaps in sustainable energy access.

- Including energy efficient appliances in a comprehensive approach to sustainable energy programs and projects by creating incentives to ensure appliances are accessible for women living in poverty.

- Designing measures to ensure that everyone, not only men, are accruing the benefits from productive process mechanization derived from the introduction of new, energy efficient technologies.

- Supporting policies and programs to encourage women to participate as distributors, sellers, maintenance and repair technicians for energy efficient appliances, to promote this valuable economic activity while contesting gender norms and improving women's status in their communities. 

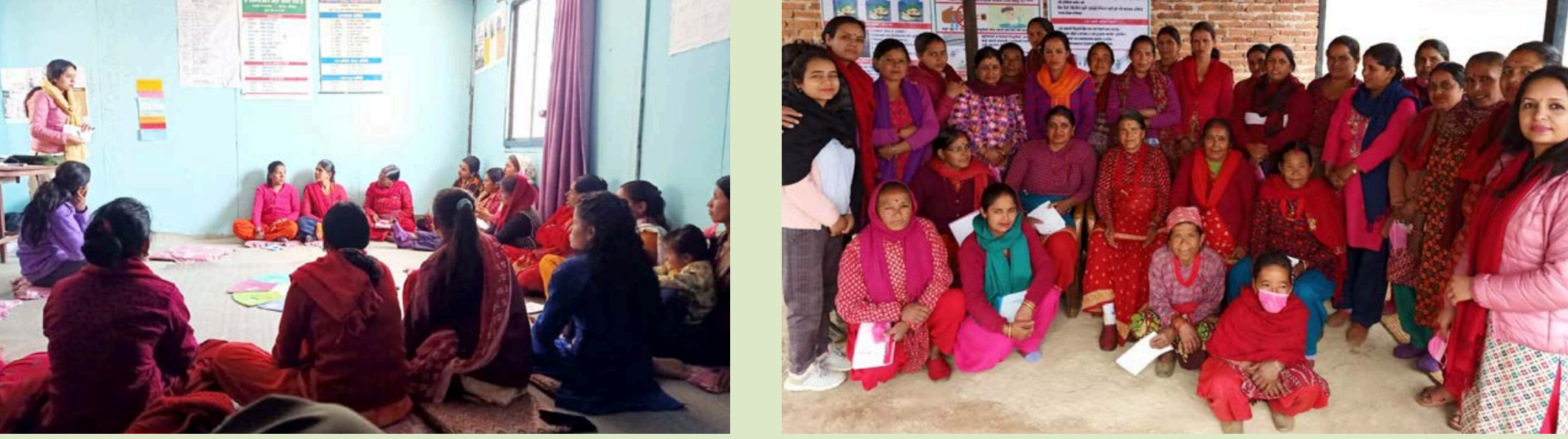

CASE STUDY:

\section{Nepalese Women's Participation in Electrical Appliances Repair and Maintenance}

In Nepal, more than $68.7 \%$ of total households are presently using solid fuels and traditional cook stoves to prepare food and heat their houses. Widespread use of traditional cook stoves has adversely affected peoples' lives in several ways, including production of harmful black carbon emissions and other pollutants, time spent gathering fuel, deforestation due to fuelwood collection and increased greenhouse gas emissions. Indoor air pollution kills 113 per every 100,000 people in Nepal, the highest mortality rate in South Asia, and more than three times the global average. There is thus an urgent need for transition to cleaner cooking solutions.

The Women Network for Energy and Environment (WoNEE) aims to ensure women's human rights, access to energy and environmental justice through wider advocacy campaigns, training and grassroots social mobilization. It was established to increase the role of women in decision-making processes as well as employment and benefits ensuing from the energy and environment sector. WoNEE has a number of local networks at different municipalities working on women's empowerment through training at the local level. Using this bottom-up approach, WoNEE is playing a vital role bringing local issues into the national energy policy discourse.

As part of one of its goals, energy-based skill enhancement for economic empowerment of women, WoNEE has been conducting training activities on safe and efficient energy use on a regular basis at its 50 local networks in towns all across the country. Through practical demonstrations, presentations and trainee interaction, the 3-day training on basic electrical safety and household wiring systems prepared the women on safe household appliances use and enabled them to fix simple problems in house wiring systems. WoNEE has also started training women entrepreneurs from low-income communities 


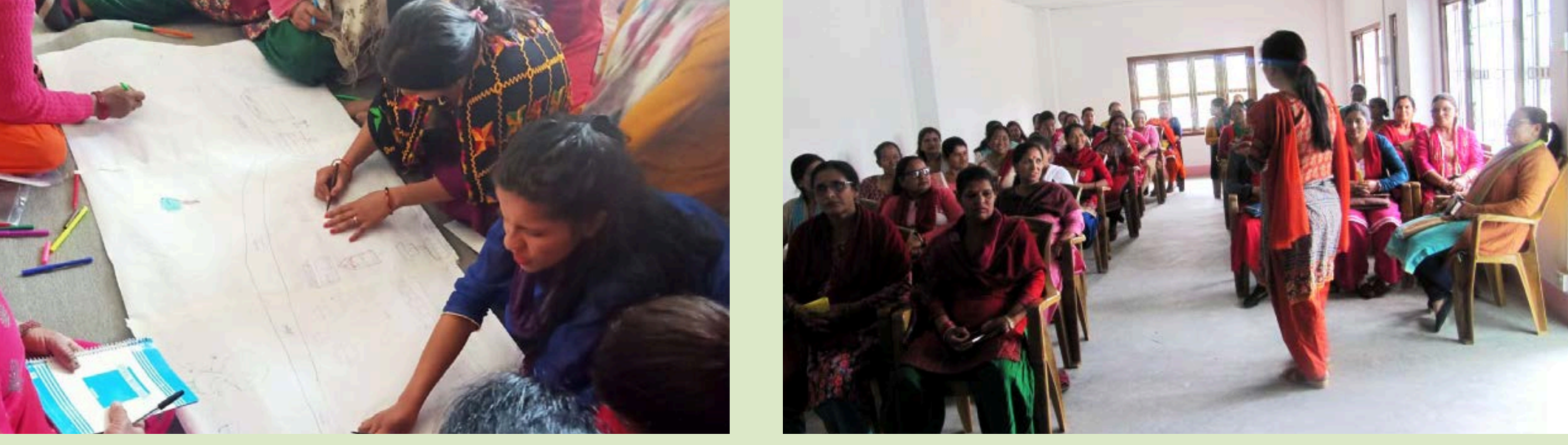

who own electrical appliance stores to repair and maintain electrical appliances, especially e-cooking technologies.

The focus areas of the training are the firstphase target areas of the Nepalese government's promotion of e-cooking in the Lalitpur, Bhaktapur and Kavre districts as well as four districts in Province Two (Rautahat, Dhanusha, Mahottari and Sarlahi). In five days' intensive training on electrical appliances repair and maintenance, through theory and practical sessions and a subsequent refresher, WoNEE has trained participants to repair household appliances. As a result, women community members living in poverty have simultaneously, reduced their economic dependency on other family members and increased their family's income. Through these trainings, WoNEE has seen a boost in women's confidence levels while participating in the electrical appliance sector their male counterparts dominate.

Considering that energy-efficient appliances ate essential for household and productive energy uses, this program is providing women with opportunities to have access and control of these tech devices, while participating in income earning activities that challenge gender roles foster energy efficiency and provide better standards of living for their families and communities.

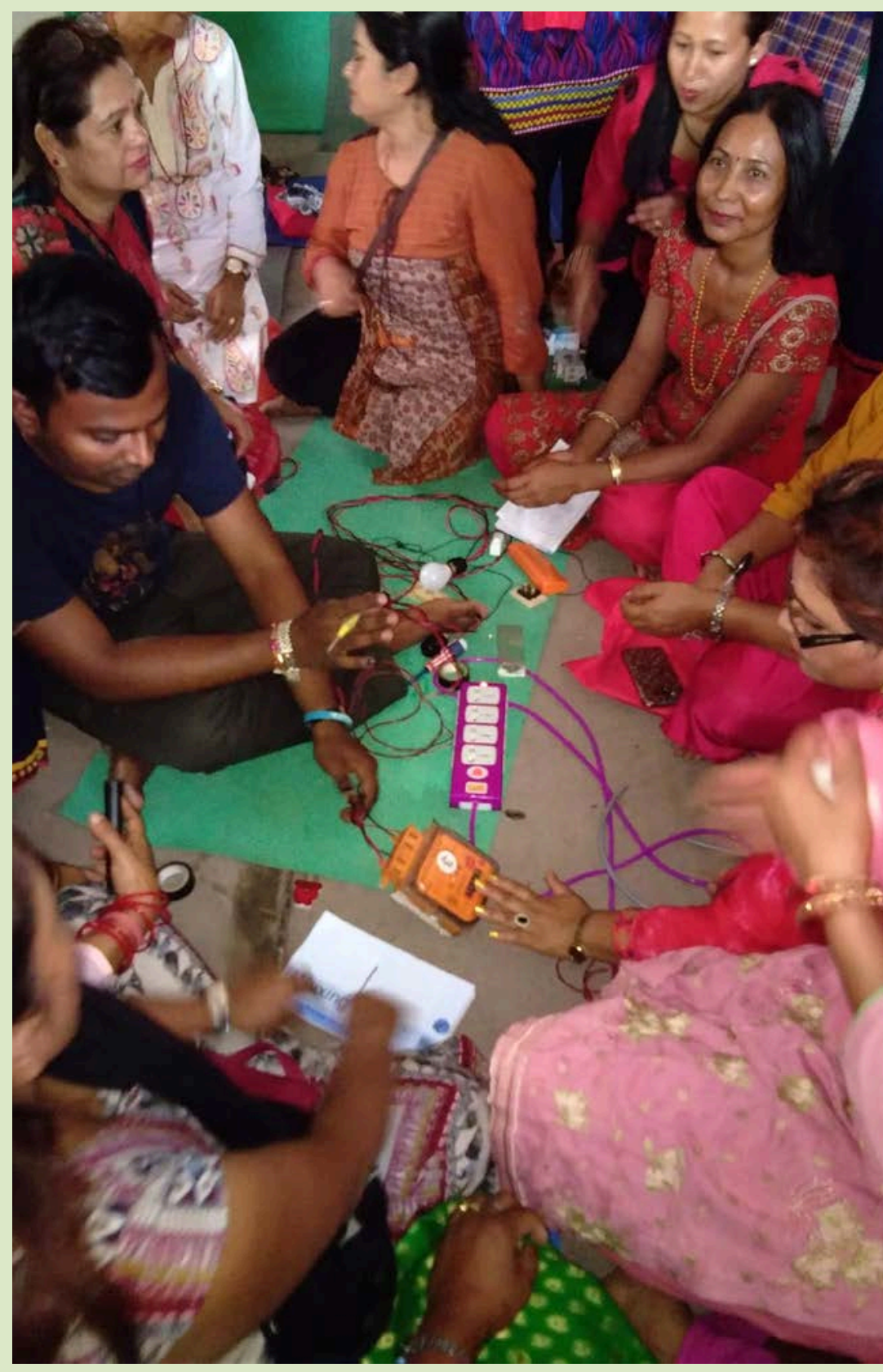




\section{Supporting Women's Traditional Knowledge and Innovation Abilities}

At the community level, women have traditional knowledge and skills for innovative energy solutions and energy efficient appliances as well as practices that are often ignored by most stakeholders advancing a just energy transition. Local knowledge systems are key to developing technologies and management techniques to address everyday life challenges and improve living standards.

On the one hand, local women have grassroots knowledge and skills related to natural resources and the environment that can play a key role in new renewable energy systems. A good understanding of, among other things, the characteristics and temporality of the seasons, water and wind flows and rain cycles is key to developing effective and resilient renewable energy systems responsive to local environments. On the other hand, innovative local technologies and devices have also been developed by community women to address energy challenges. For instance, a group of women living in a marginalized community in Tacna, Peru, who did not have access to electricity in their households, developed their own lantern by improving the mecha chua, a traditional handmade candle. ${ }^{104}$ The renewed candle was cheaper, saved fuel, made kerosene fumes less harmful, prevented more accidents, and provided light for longer hours. ${ }^{105}$

Supporting women's local and traditional knowledge and skills could be a rich and essential source of information for the development of culturally adequate renewable energy systems, energy efficient technologies and infrastructure, as well as improving the status of women in their communities by recognizing their critical role as key agents of change and valuable knowledge sources. Developing renewable energy systems in close consultation and with the participation of local women, including Indigenous women is, therefore, essential for a gender-just energy transition.

\footnotetext{
104 Cecelski, Elizabeth, "The Role of Women in Sustainable Energy Development," National Renewable Energy Laboratory, 2000.

105 Ibid.
} 


\section{Gender-sensitive and Participatory Decision-making}

\section{Ensure a Gender-Balanced Composition of Energy-Related Governance Bodies}

Promoting gender parity in energy decision-making forums, platforms and governance bodies is critical to fostering women's participation in energy transition. States should take necessary steps to achieve a gender-balanced composition of all bodies intervening at all stages of decision-making through multifaceted approaches that are responsive to the challenges faced by women due to intersectional forms of discrimination. This might be achieved by:

- Designing participatory mechanisms that consider gender inequalities and asymmetries of power in a given context, and that implement necessary measures to counteract them.

- Ensuring that conditions for participation in decision-making and governance bodies, directly or indirectly, do not unfairly exclude women; and

- Considering temporary measures to encourage women to participate, such as establishing quotas and other forms of affirmative action.

\section{CASE STUDY:}

\section{Rwanda's Gender-Quotas in Governance Bodies}

The Rwanda Constitution's Article 9(4) states women should be granted at least $30 \%$ of posts in all decision-making organs, including all governance bodies relevant to energy transition processes. While acknowledging that women's inclusion in relevant decision-making bodies is not enough, it would increase women's bargaining power and encourage them to become role models who challenge gender roles, discriminatory social norms and other such practices. This is a critical first step to ensure women's right to participation in energy planning and policymaking. 


\section{Environmental and Human Rights Impact Assessments}

In most countries around the world, during the energy planning process, developers need to conduct Environmental Impact Assessments (EIA). This process allows for an evaluation of how local communities and the natural environment might be potentially harmed or benefited from the implementation of a given policy or project. This exercise provides energy developers with key information to undertake measures to avoid, mitigate and monitor any potential negative impacts on local populations and ecosystems. ${ }^{106}$ This is usually a legal requirement for most energy projects and policies, but is especially relevant for developing large-scale renewable energy projects that are land-intensive, and which could generate social tensions and conflicts with local populations.

The evaluation on the potential impacts of the energy project or policy must be comprehensive and include gender and human rights considerations, as well as be developed with the meaningful participation of all those who will be affected by the energy intervention. ElAs should also be conducted at each point of renewable energy life cycles, from extraction of the necessary minerals on which renewable energy technologies depend to the construction, installation, and distribution of renewable energy for productive uses.

At a minimum, the impact assessments for renewable energy projects and policies should consider the following elements:

- Public participation of persons and communities who will be especially affected at an early stage of the evaluation process and sustain this participation until the conclusion and publication of the environmental impact assessment results.

- Design the process to prioritize participation of those most affected by the policy or projects, integrating a gender lens to ensure women in all their diversity are able to participate.

- Guarantee that women's perspectives, needs and concerns are adequately considered in the project or policy's final assessment.

- Ensure the impacts assessment is developed by an independent, impartial and objective entity seeking to increase participants and energy developers' knowledge of a given policy or project.

- Ensure the impact assessment considers not only specific, but cumulative impacts of all the activities and operations the given project or policy implies.

106 IUCN and USAID, "Advancing Gender in the Environment: Making the Case for Gender Equality in Large-Scale Renewable Energy Infrastructure Development,' AGENT Thematic Brief Series, 2018, ss. 


\section{Gender-Sensitive Consultation Processes}

Consultation processes with the full and effective participation of Indigenous and local communities whose interests and livelihoods might be affected by the implementation of renewable energy projects and policies should be undertaken to decide whether these should move forward, and if so, under which conditions. Consultation processes should thus be designed and implemented according to international human rights standards in a manner that allows all persons regardless of their gender to equally participate: ${ }^{107}$

- Identifying a time and location that do not compete with housework and caregiving activities and that are otherwise accessible and convenient for women.

- Ensuring information has been disseminated in a format and through channels that are understood and frequented by women according to their social practices, literacy levels and languages.

- Organizing discussions in forms that are culturally and socially appropriate and that make women feel safe and comfortable sharing their views and experiences.

- Giving equal importance and weight to the needs and concerns of everyone affected regardless of their gender.

- Ensuring that participation is not conditioned to the ownership of assets, e.g., land tenure rights, or other requirements that might exclude women.

- Taking into consideration the results of the consultation process from the outset and in all stages of the development and implementation of a policy and project.

- Making the results of the consultation publicly available recognizing gender differentiated demands and concerns.

In relation to the outcome of the consultation process, one must consider that the extent to which a process of this kind can facilitate genuine intercultural negotiations depends on the strength of women's and the community's political organization. At the same time, participation in consultation processes in itself also allows for generating a political organizational potential that strengthens the participants' strategic capacity and collective identification with regard to common demands and advocacy strategies.

107 Ibid. no. 126 

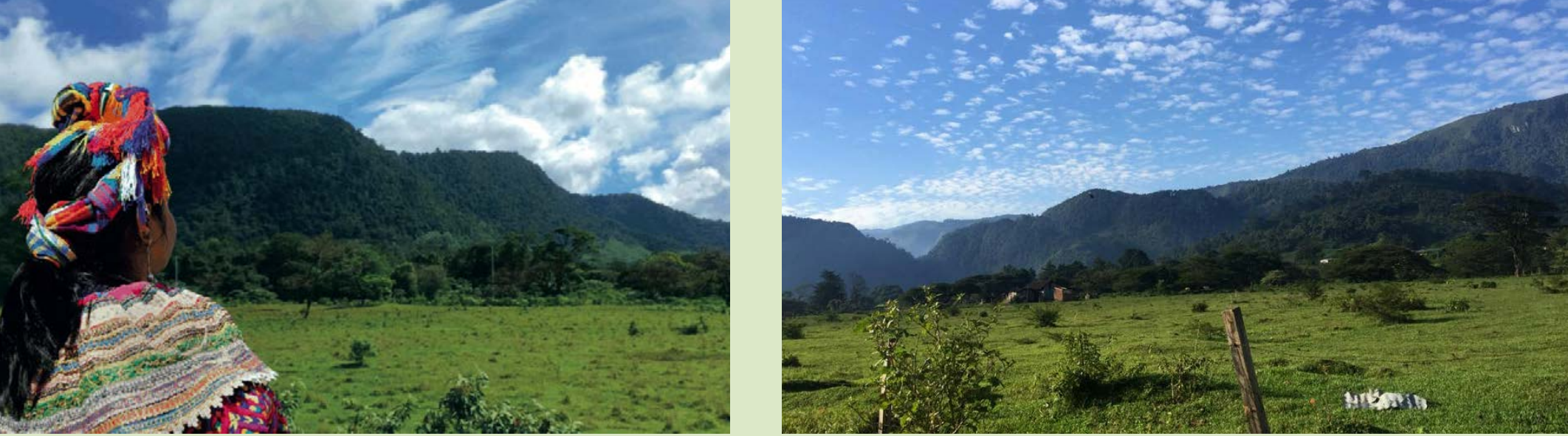

CASE STUDY:

\section{Denouncing Violation of the Right to Free, Prior and Informed Consent in Development of the Ixquisis, Guatemala Hydroelectric Complex}

The Association for the Defense of the Environment (AIDA), an environmental organization working in Latin America, has been supporting several Maya women who live in the mountains of northwestern Guatemala, near the Mexican border. These Indigenous communities have long depended on the waters to nourish them, to provide them with fish, and to keep crops alive.

However, life in the microregion of Ixquisis, in Huehuetenango Department, has changed drastically in recent years. Several large dams have been constructed in the watershed, including the Pojom II and San Andrés dams, both of which were financed by a private lending arm of the Inter-American Development Bank (IDB). As it has been widely documented by AIDA, these projects were authorized by the authorities without complying with the effective, transparent and inclusive processes that define a participatory consultation under international human rights law.
The dams have caused water scarcity and polluted the river long cherished by the communities. Fish are no longer abundant, and stomach and skin diseases have become commonplace. The women have been the most impacted as the river is where they gather, wash themselves and their clothes, and begin to prepare food to feed their families. The near lack of water has also drastically reduced harvests, lessening the income gained from selling corn, wheat, beans, coffee, sugar cane and other products in the market. As a result, the conditions of poverty in the area have deepened with a disproportionate impact on women's and girls' livelihoods.

Despite the risks, the women play an important role in their communities' opposition movement to the hydroelectric projects. As guardians of their land and water, they have come to its defense, and they'll continue speaking out to prevent environmental deterioration from further harming their 


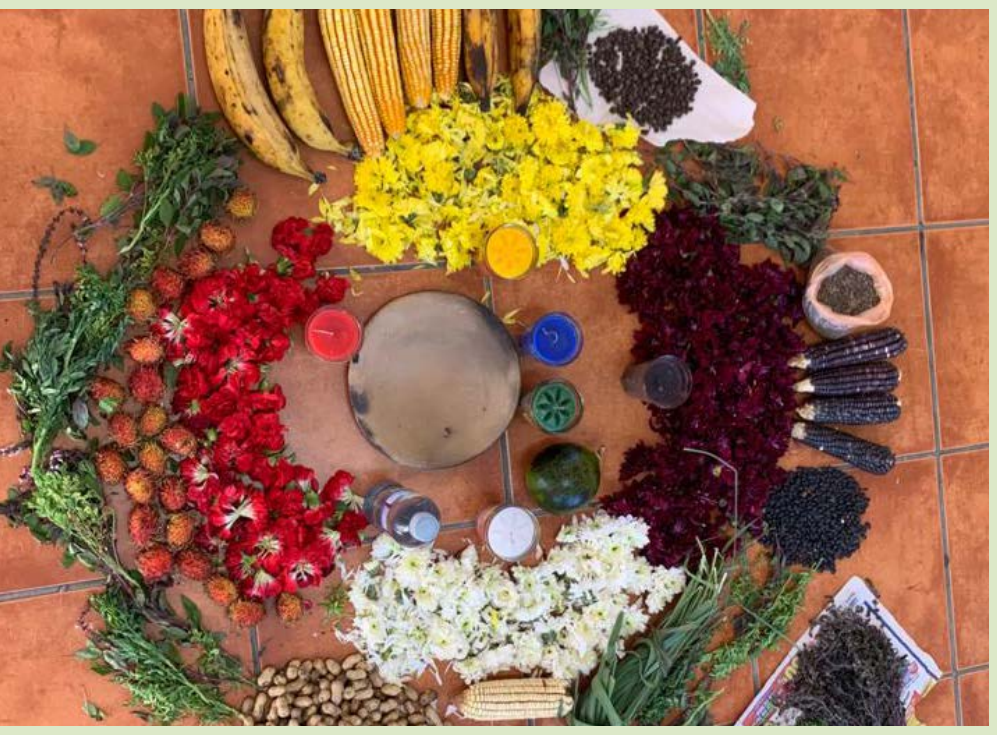

communities. They are calling for the energy developers and relevant authorities to conduct a consultation process to redress the violation of their rights. They are demanding to have a say, to participate, in the development of the energy projects developed in their territories. However, since their demands have been so far ignored, social tensions have scaled in the community. The women of the community, with AIDA's assistance, has submitted a complaint before the Independent Consultation and Investigation Mechanism ( $\mathrm{MICl}$ ), the organ that addresses the complaints from communities harmed by projects funded by the Inter-American Development Bank Group seeking for redress and halt to the hydroelectric project.

This case illustrates the implications of a transition to renewable energies that fails to conduct adequate gender-responsive and participatory social and environmental impact assessments and that does not comply with the obligation to consult energy projects and policies with local communities.

Note: Case study provided by AIDA

https://aida-americas.org/
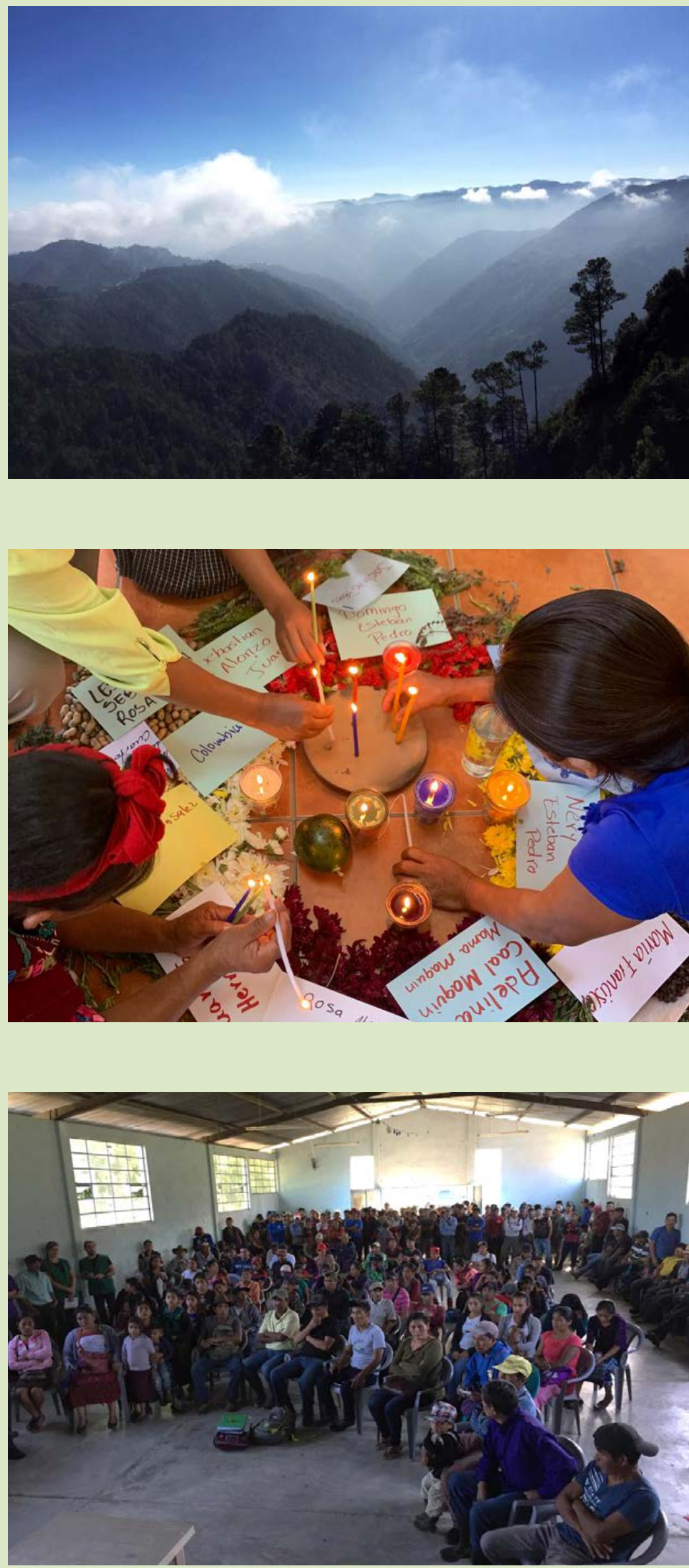


\section{Enabling Platforms for Women to Exchange Experiences, Mutual Learning, and Organizing}

Supporting and protecting platforms for women to learn, exchange experiences and organize is key to ensuring their meaningful participation in the energy transition. This involves the creation of spaces and platforms for women to feel comfortable to share their views, have peer-to-peer exchanges, identify common challenges and demands, as well as to coordinate with others to influence decision-making processes. Fostering participatory spaces also entails protecting the right of women to protest and to oppose specific energy transition policies and projects. In other words, to protect community and civil society spaces, States should consider:

- Supporting and fostering platforms for women to learn, organize, share experiences and information on energy policies and projects and their impacts on their rights and livelihoods.

- Ensuring institutional, legal, and policy frameworks for the enjoyment of women's right to freedom of assembly and association.

- Ensuring enabling environments for women human rights defenders protesting or opposing specific energy policies and projects to conduct their work safely.

- Protecting participatory spaces from retaliation or interference by State and non-state actors. 


\section{CASE STUDY:}

\section{Empowering Women to Combat Energy Poverty Through Collective Advisory Assemblies}

Mediterranean countries' coastal areas have a surprising proportion of low-income households. The area is remarkable mainly because during the summer season, the cooling component of energy poverty is highlighted. Lack of pre-installed central heating systems and electricity-based heating, which is generally speaking more expensive, is another specificity of this region. Dwellings have insufficient or zero insulation and there is a high level of deteriorated housing stock, which makes the situation more challenging. The region also faces challenges of austerity-induced energy vulnerability. Additional key area aspects are arrears, indebtedness and the risk of disconnection, as well the link between energy poverty and housing insecurity with evictions as the worst consequence of housing unaffordability. Lastly, coastal urban areas are also affected by precarious, low-quality jobs.
In this context, women and women-led households are disproportionately affected by energy poverty. Due to gendered labor division, which means women bear the main exertions of unpaid caregiving, and tend to spend more time working at home, thus are more exposed to energy poverty and its consequences. Women are also more heat and cold sensitive than men due to physiology (chronic temperature-related discomfort, heat and associated maladies).

To address these challenges, the EmpowerMed project ("Empowering Women to Take Action Against Energy Poverty in the Mediterranean") aims to contribute to energy poverty alleviation and improve the health of people affected by energy poverty in Mediterranean countries' poor coastal areas, with a particular focus on women. The project mainly contributes through empowering people affected by 
energy poverty to manage their energy consumption and improve their access to appropriate energy resources. The project connects nine partners from seven countries, specifically Focus (Slovenia), DOOR (Croatia), Sogesca (Italy), UAB, IREC and ESF (Spain), WECF (Germany) and Milieukontakt (Albania).

EmpowerMed tackles energy poverty through, among other methods, collective advisory assemblies that gather about 20-30 people affected by energy poverty in common spaces to help transfer and exchange knowledge and skills about energy use, reading energy bills, implementing simple measures for energy savings, changing energy providers, organizing collective energy purchases, accessing building rehabilitation grants and any other action that can reduce the effects of energy poverty.

These families or individuals receive advice and devices, following peer-to-peer methodologies that could also mean accompanying families to utility companies to change or cancel contracts. The main characteristic of the community approach is that it uses the network's collective intelligence to engage members to support one another. The collective support group is an indispensable tool for transformation, collectively facing a set of problems that would otherwise overwhelm those affected. Over 6,250 people are estimated to participate across the region in this activity.

EmpowerMed has the main purpose to empower women affected by energy poverty to trigger transformative changes in domestic energy use practices and replicate exemplary cases of gendered local energy poverty alleviation approaches.

Note: This case was provided by EmpowerMed partners. EmpowerMed has received funding from the European Union's Horizon 2020 research and innovation program under grant agreement No 847052.

More information about EmpowerMed is available at https://www.empowermed.eu/. 


\section{Ensuring Women's Participation in Urban Planning}

Urban planning and development are key to ensure a just transition to green energy. It can be achieved with decentralized renewable energy infrastructure, fostering women's representation in local government and promoting energy efficiency in buildings, public lighting and transportation. Also important is provision of public services, such as education, health, potable water and sanitation. Cities fostering renewable energy solutions and greater energy efficiency should also make significant efforts to organize public education campaigns that raise awareness and encourage transformative changes in citizens' consumption patterns to save energy, especially among higher income consumers. Local authorities should offer advice and subsidies to promote energy efficiency and renewable energy installations that develop more sustainable urban energy systems adaptable to local needs and able to empower women to lead energy solutions in their communities. We need to open spaces to reimagine urban development by including women's resounding voices, women's rights organizations and social movements in local urban political institutions to foster sustainable city planning.

\section{Finance and Budgeting}

\section{Ensure Gender-Sensitive Finance and Budgeting}

It is imperative to promote financing energy projects and policies that deliver gender equal outcomes and promote the role of women as key agents of change in the articulation of socially inclusive and sustainable energy solutions. There is a wide variety of measures that States could take in this regard, including:

- Cease financing fossil fuel energy projects as a means to close gaps in energy access.

- Expand the investment portfolios of international financial institutions and other development investment funds to include renewable energies that pursue gender equality outcomes by incorporating co-benefits and links to economic, social and cultural rights.

- Establish taxes on carbon and pollution to create opportunities for States to invest in a gender-just transition to renewable energy. 
- Remove barriers for micro, small and medium renewable energy enterprises to access finance and facilitate funds for women-led initiatives.

- Incorporate a gender perspective at all levels of the energy budgetary process and restructure revenues and expenditures to address gender deficits in the energy sector and advance substantive gender equality in the energy transition process.

- Promote alternative forms financing by means of loans, micro-credits and subsidies, to encourage marginalized women to participate in providing renewable energy solutions.

A gender-just transition to a new energy economy will not only require ensuring the necessary funds, but also must ensure these are granted to projects with women beneficiaries, as well as to initiatives that favor activities that prioritize women's needs and pay attention to who has control over provided resources. Funding must be directed toward long-term sustainable and gender-sensitive objectives that promote the participation of women at all levels of decision-making. 


\section{CASE STUDY:}

\section{Providing Micro Credits for Gender-Responsive Solar Home Systems in Rural Bihar, India}

The state of Bihar is one of India's most socially and economically underdeveloped provinces, having one of the lowest per capita incomes and high incidence of poverty (nearly a third of the people are below poverty line. JEEViKA is a livelihood program from the Bihar Rural Livelihood Promotion Society (BRLPS) focused on enhancing rural women's economic and social justice. The program initiated in 2006 and focuses on developing women's Self-Help Groups (SHG), a financial intermediary committee composed of community men and women who pool resources and provide financial help to their fellow member(s) in the form of loans, whenever necessary. Under the "JEEViKA—Lighting a Billion Lives (LaBL)" initiative, women are the main targeted beneficiaries. The women receive a clean energy loan called an "Energy Security Credit" to help finance the system cost of a solar-home system to provide access to sustainable sources of energy in poorly electrified villages.
To coordinate this program, the Energy and Resources Institute (TERI)-a national, independent, multi-dimensional organizationadopted an innovative approach for delivery of the clean energy system by providing the required technical support and viability gap funding for purchase of solar house systems; whereas JEEViKA focused on field coordination in charge of community member awareness and providing small loans to members interested in acquiring the solar system. The energy package promoted under the initiative includes two LED lamps and a mobile charging point powered by a 20-25 Wp solar panel and a battery. Later, a forced-draft improved cookstove was added to the solar house system as a package named "Integrated Domestic Energy Systems."

Since the introduction of the program, women have experienced a positive shift in confidence. They can support their families through access to loans that were not so available earlier. The most notable benefit of 
the collaborative initiative has been the opportunity it gave women to make decisions regarding energy system purchase and ownership. This decision-making capacity has not only contested energy-patriarchy but also contested the functional patriarchy of the households where men were regarded as bread-winners and as such, decision makers. The time-savings the solar lighting facilitated is also contributing to increasing women's choices. Though women's future financial autonomy is still likely to be modest, in comparison to men's, the abovementioned benefits of this program are signs of the improvement of women's income levels.

Changes in gender relations, however, require socio-cultural changes on a deeper level over time. But this does not mean the goal of increasing access and ownership of electricity systems to women should be abandoned. Rather, energy access policies and projects must work in tandem with supporting policies on education, health, social security, among others, to transform uneven gender relations. The project can be seen as an example which has given women an opportunity to make choices and decisions and increased their bargaining power in the household, challenging some of the existing patriarchy and gender roles in energy asset ownership.

Note: The Energy and Resources Institute provided this case study. (https://www.teriin.org/). 
- International Convention on the Rights of All Migrant Workers and Members of their Families (ICRMW) - arts. 41 and 42.2

- International Labor Organization Convention No. 169 on Indigenous and Tribal Peoples Convention (ILO Convention 169)- arts. 6 and 7.

- The American Convention on Human Rights-art. 23

- African Charter on Human and Peoples' Rights- art. 13.

\section{Non-binding international human rights instruments}

- Universal Declaration of Human Rights - arts. 21 and 27

- United Nations Declaration on the Rights of Indigenous Peoples arts. 5, 18, 19 and 41

- Beijing Declaration and Platform for Action - arts.13, 16, 19, 20 and 34.

- UN Guiding Principles on Business and Human Rights - especially art. 18(b)
- Convention on Environmental Impact Assessment in a Transboundary Context (Espoo Convention) -art.2.

\section{Non-binding international environmental and sustainable development instruments}

- Rio Declaration on Environment and Development, Principle 10

- Sustainable Development Goals (SDG) - SDG 5, SDG 7, and SDG 13

- UNGA Res 75/221 (on energy, §17), 75/217 (on global climate, §20), 75/216 (on DRR, §§41-42)

- Guidelines for the Development of National Legislation on Access to Information, Public Participation and Access to Justice in Environmental Matters (UNEP Bali Guidelines)

- Lima Work Program on Gender and its Gender Action Plan.

- Enhanced Lima Work Program on Gender and its Action Plan.

- $\quad$ Paris Implementation Guidelines.

- $\quad$ UNFCCC Decision 36/CP.7 Improving the Participation of Women in Bodies Under the UNFCCC. 
- UNFCCC Decision 23/CP.18

Promoting Gender Balance

and Improving the Participation

of Women in UNFCCC Negotiations

and in the Representation of Parties

in Bodies.

- Doha Work Program -

Annex 1 § 15

- Decision 17/CP.22 of the

Doha Work Program

- World Charter of Nature, § 23

- International Law Commission, draft articles on Prevention

of Transboundary Harm

from Hazardous Activities,

with commentaries, art. 13.

The right to participate as enshrined in human rights instruments, has been further developed and fleshed out through the work of UN treaty bodies and special procedures. Since the UN treaty bodies are those mandated to monitor compliance with respective international human rights treaties, these statements-although not legally binding-are a key source of authoritative legal standard.

The Human Rights Committee, which is in charge of supervising States' compliance with the International Covenant on Civil and Political Rights (ICCPR) has released General Comment 25 on article 25 which focuses on the right to participate in public affairs and the right to vote and highlights non-discrimination and equality as key values for the fulfilment of this human right. ${ }^{108}$ This comment is further supported by the Human Rights Committee's General Comment 28 on Article 3 concerning the equality of rights between men and women which States that are parties to the Covenant must "take effective and positive measures to promote and ensure women's participation in the conduct of public affairs and in public office, including appropriate affirmative action." 109

108 UN Human Rights Committee (CCPR), "General Comment 25" (1996), adopted by the Human Rights Committee under Article 40, Paragraph 4, of the International Covenant on Civil and Political Rights, UN Doc CCPR/C/21/Rev.1/Add.7, paragraph 3

109 CCPR, "General Comment 28 on Article 3" ("The Equality of Rights Between Men and Women") (2000), UN Doc HRI/GEN/1/Rev.9 (Vol. I), paragraph 29. 
The Committee on the Elimination of All Forms of Discrimination Against Women (CEDAW Committee), is the expert body established to oversee the implementation of the UN Convention on the Elimination of all Forms of Discrimination Against Women, published its General Recommendation 23 on women in political and public life in 1997. This landmark instrument specifies that women's right to participation extends to all areas of public and political life. ${ }^{110}$ It goes further by highlighting the importance of temporary special measures to encourage equal participation and that "women also require the encouragement and support of all sectors of society to achieve full and effective participation." 111 In a similar vein, CEDAW Committee further specified in General Recommendation 34 that States should ensure rural women "are able to participate effectively in planning and decision-making relating to rural infrastructure and services, including [...] energy. "112

In the climate change context, CEDAW Committee has underscored the importance of women's right to participation in decision-making and development planning with regard to disaster-risk reduction and climate change. ${ }^{113}$ Specifically, it highlighted that while climate change mitigation and adaptation programs may provide new employment and livelihood opportunities in sectors such as clean energy, failure to address the structural barriers women faced in gaining access to their rights will increase gender-based inequalities and intersecting forms of discrimination. ${ }^{114}$

The reports issued by UN Special Procedures also provide guidance and expert advice to States and other relevant stakeholders on key human rights issues. In relation to women's participation, the Special Rapporteur on Human Rights and the Environment highlighted States' obligation to "ensure an inclusive, equitable and gender-based approach to public participation in all climate-related actions," specifically through empowering women. ${ }^{115}$ The Special Rapporteur on the Rights of Indigenous Peoples further emphasized the importance of

\footnotetext{
110 UN Committee on the Elimination of All Forms of Discrimination Against Women (CEDAW Committee), "General Recommendation 23 on Women in Political and Public Life," 1997, paragraph 5.

111 Ibid. paragraph 15 .

112 CEDAW Committee, "General Recommendation 37 on the Gender-Related Dimensions of Disaster Risk Reduction in the Context of Climate Change," 2018, UN Doc CEDAW/C/GC/37, paragraph 54(d).

113 Ibid. paragraph 36

114 Ibid. paragraph 3.

115 HRC, Report of the Special Rapporteur on the Issue of Human Rights Obligations Relating to the Enjoyment of a Safe, Clean, Healthy and Sustainable Environment, David R. Boyd, 2019, UN Doc A/74/161, paragraph 64(b).
} 
Indigenous women's participation (and especially the participation of Indigenous women human rights-defenders) in decision-making. ${ }^{116}$ The Special Rapporteur on Extreme Poverty and Human Rights has also developed a framework for a rights-based form of participation to ensure that the poorest and most marginalized people can make their voices heard. ${ }^{117}$ More recently, in 2019, the Office of the High Commissioner's Report submitted to the Human Rights Council specifically looking at gender-responsive climate action, stated that "the full and equal participation and leadership of women in decision-making, planning and implementation as regards climate action is essential to protecting women's rights and ensuring effective climate action." 118

In relation to landmark political and non-binding women's rights instruments, the Beijing Declaration and Platform of Action specifically refers to women's participation in renewable energy. The Declaration establishes the need to "promote knowledge of and sponsor research on the role of women," including in new and renewable energy sources. ${ }^{119}$ Furthermore, it recommends women's priorities be included in public investment programs such as electrification and energy programs, ${ }^{120}$ and highlights the need for States to support women's equal access to sustainable and affordable energy solutions. ${ }^{121}$

In the agreed conclusions of the $63^{\text {rd }}$ session of the UN Commission on the Status of Women (CSW), States highlighted the importance of women's full and equal participation in public affairs as a crosscutting principle. ${ }^{122}$ In relation to energy, the CSW recommend States "provide targeted support and incentives for women's participation and leadership as users and producers of energy." 123

We must, however, recognize that the right to participation does not exist in a void. Ensuring the effective and meaningful participation of women requires a

\footnotetext{
116 HRC, Report of the Special Rapporteur on the Rights of Indigenous Peoples, Victoria Tauli Corpuz, 2015, UN Doc A/74/161/HRC/30/41, paragraphs 38-39.

117 HRC, Report of the Special Rapporteur on Extreme Poverty and Human Rights, Magdalena Sepúlveda Carmona, 2013, UN Doc A/HRC/23/36, paragraph 17.

118 HRC, "Analytical Study on Gender-Responsive Climate Action for the Full and Effective Enjoyment of the Rights of Women;" Report of the Office of the United Nations High Commissioner for Human Rights, 2019, UN Doc A/HRC/41/26, paragraph 26.

119 United Nations Beijing Declaration and Platform of Action, adopted at the Fourth World Conference on Women, 1995, Art. 256(f).

120 Ibid., Art. 167(d).

121 Ibid., Art. 256(k).

122 UN Women, 63 ${ }^{\text {rd }}$ Commission on the Status of Women (CSW): "Agreed Conclusions," 2019, UN Doc E/CN.6/2019/L.3 paragraphs 8, 10 and (c).

123 Ibid. paragraph (ggg).
} 
broad set of interlinked human rights to be respected, protected, and fulfilled. For instance, the right to access information, rights to freedom of expression, assembly, association, education, to work and be free of discrimination as well as gender-based violence, are essential preconditions for the realization of the right to participation.

States therefore have a positive obligation under international human rights law to establish specific mechanisms at all relevant levels to ensure that women have the de jure and de facto opportunity to take part in decision-making that might affect them. This includes the State's responsibility to ensure that private actors, including business enterprises, foster inclusive participation and the responsibility of business to incorporate due-diligence policies and mechanisms to avoid infringing it. This is relevant especially in the context of energy transition, as it is mostly the private sector that is driving the global shift in energy systems.

Based on these international standards, the following section will analyze the different contested dimensions of the right to participation, considering its implications for the transformation of uneven power structures in energy systems. 
The Global Initiative for Economic, Social and Cultural Rights (GI-ESCR) is an international non-governmental organization.

Together with partners around the world, GI-ESCR works to end social, economic and gender injustice using a human rights approach.

This is the second briefing paper published by GI-ESCR exploring the relationship between the energy transition and women's rights. You may find our previous briefing paper on Renewable Energy and Gender Justice published in 2020 and translated into Spanish in 2021 on our website: www.gi-escr.org.

Website: www.gi-escr.org

Twitter: @GIESCR (General account) @GIESCR_LatAm (Latin America) Facebook: @GIESCR

Instagram: @giescr

LinkedIn: Global Initiative for Economic, Social and Cultural Rights

\section{The Global Initiative}

for Economic, Social and Cultural Rights

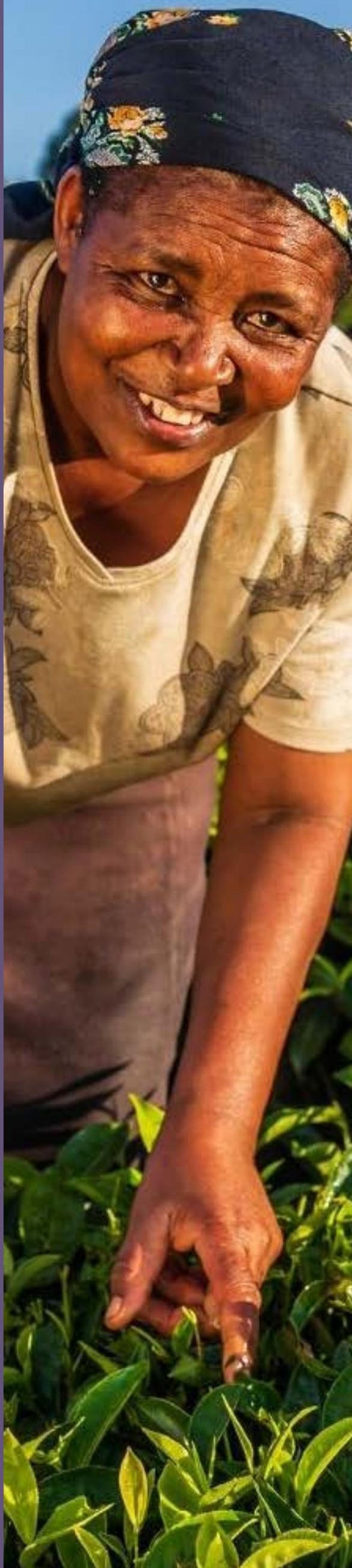

